\title{
Soil-erosion and runoff prevention by plant covers. A review
}

\author{
Víctor Hugo Durán ZUAZO ${ }^{1,2 *}$, Carmen Rocío RodRíGuez PleGUeZUELo ${ }^{1,2}$ \\ ${ }^{1}$ IFAPA Centro Camino de Purchil, Apdo. 2027, 18080-Granada, Spain \\ ${ }^{2}$ USDA-National Soil Erosion Research Laboratory, 275 S. Russell Street, West Lafayette, IN 47907-2077, USA
}

(Accepted 10 December 2007)

\begin{abstract}
Soil erosion is a critical environmental problem throughout the world's terrestrial ecosystems. Erosion inflicts multiple, serious damages in managed ecosystems such as crops, pastures, or forests as well as in natural ecosystems. In particular, erosion reduces the waterholding capacity because of rapid water runoff, and reduces soil organic matter. As a result, nutrients and valuable soil biota are transported. At the same time, species diversity of plants, animals, and microbes is significantly reduced. One of the most effective measures for erosion control and regeneration the degraded former soil is the establishment of plant covers. Indeed, achieving future of safe environment depends on conserving soil, water, energy, and biological resources. Soil erosion can be controlled through a process of assessment at regional scales for the development and restoration of the plant cover, and the introduction of conservation measures in the areas at greatest risk. Thus, conservation of these vital resources needs to receive high priority to ensure the effective protection of managed and natural ecosystems. This review article highlights three majors topics: (1) the impact of erosion of soil productivity with particular focus on climate and soil erosion; soil seal and crust development; and C losses from soils; (2) land use and soil erosion with particular focus on soil loss in agricutural lands; shrub and forest lands; and the impact of erosion in the Mediterranean terraced lands; and (3) the impact of plant covers on soil erosion with particular focus on Mediterranean factors affecting vegetation; plant roots and erosion control; and plant cover and biodiversity.
\end{abstract}

soil degradation / soil erosion / biomass / soil productivity / sustainability / climate / global warming / C

\section{INTRODUCTION}

Worldwide, agricultural production occupies about $50 \%$ of the terrestrial environment. Soil degradation is as old as agriculture itself, its impact on human food production and the environment becoming more serious than ever before because of its extent and intensity. Soil erosion exacerbates the loss of soil nutrients and water, pollutes surface waterways, constitutes the prime cause of deforestation, contributes to global change, and reduces agricultural and environmental productivity. Each year, about 75 billion tons of soil is eroded from the world's terrestrial ecosystems, most from agricultural land at rates ranging from $13 \mathrm{Mg} \mathrm{ha}^{-1} \mathrm{yr}^{-1}$ to $40 \mathrm{Mg} \mathrm{ha}^{-1} \mathrm{yr}^{-1}$ (Pimentel and Kounang, 1998). According to Lal (1990) and Wen and Pimentel (1998) about 6.6 billion tons of soil per year is lost in India and 5.5 billion tons are lost annually in China, while in the USA, soil loss is more than 4 billion tons per year. Because soil is formed very slowly, this means that soil is being lost 13-40 times faster than the rate of renewal and sustainability. Rainfall energy is the prime cause of erosion from tilled or bare land, occurring when the soil lacks protective vegetative cover.

According to Naylor et al. (2002) the effects of vegetation on soil can be divided into two major related categories: bioprotection and bioconstruction. Plant cover protects soil against erosion by reducing water runoff (Rey, 2003; Puigdefabregas, 2005, Durán et al., 2006a; 2007) and by in-

\footnotetext{
*Corresponding author: victorh.duran.ext@juntadeandalucia.es
}

creasing water infiltration into the soil matrix (Ziegler and Giambelluca, 1998; Wainwright et al., 2002).

Plants shelter and fix the soil with their roots (Gyssels et al., 2005; de Baets et al., 2007a, b) reduce the energy of raindrops with their canopy (Bochet et al., 1998; Durán et al., 2007). Also, vegetation can act as a physical barrier, altering sediment flow at the soil surface (Van Dijk et al., 1996; Lee et al., 2000; Martínez et al., 2006). The way the vegetation is spatially distributed along the slopes is an important factor for decreasing the sediment runoff (Lavee et al., 1998; Calvo et al., 2003; Francia et al., 2006). This barrier effect can lead to the formation of structures called phytogenic mounds. Such structures are found on the upslope side of large strips of grass disposed perpendicular to the slope (Meyer et al., 1995; Van Dijk et al., 1996; Abu-Zreig et al., 2004). Several mechanisms are involved in mound formation: the differential erosion rates in the closed environment of the plant (Rostagno and del Valle Puerto, 1988), or the deposition of sediment resulting from a decrease in overland water flow (Sanchez and Puigdefabregas, 1994; Bochet et al., 2000). On the other hand, Van Dijk et al. (1996) pointed out the interest in the relationships between plant morphology and the effects on soil erosion, showing that plant length and a complete canopy are key features for sediment trapping.

The importance of plant cover in controlling water erosion is widely accepted. In the short term, vegetation influences erosion mainly by intercepting rainfall and protecting the soil surface against the impact of rainfall drops, and by 


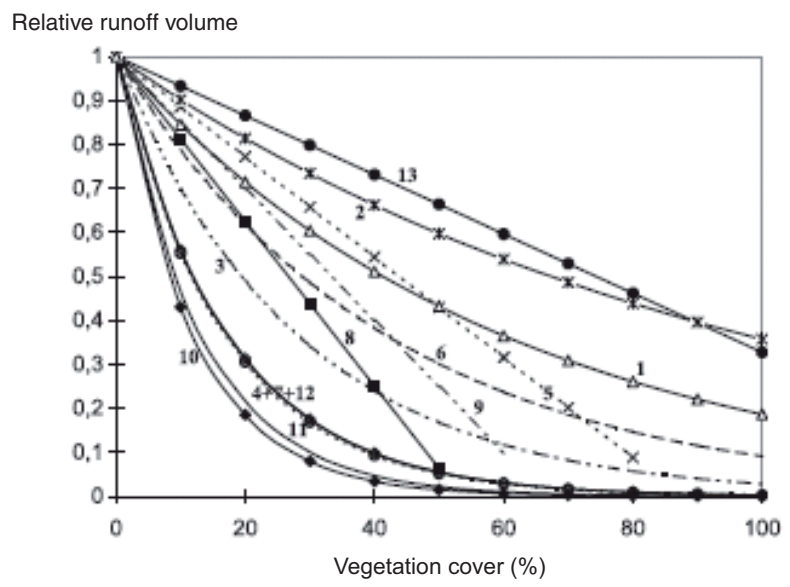

Figure 1. Relationship between plant cover and relative runoff. 1, 2, Packer (1951); 3, 4, Marston (1952); 5, Branson and Owen (1970); 6, Elwell and Stoking (1976); 7, Lang (1979); 8, 9, Kainz (1989); 10, 11, Francis and Thornes (1990); 12, Lang (1990); 13, Greene et al. (1994).

intercepting runoff. In the long term, vegetation influences the fluxes of water and sediments by increasing the soil-aggregate stability and cohesion as well as by improving water infiltration. This complex relationship has usually been reported as a negative exponential curve between vegetation cover and erosion rates for a wide range of environmental conditions. Concerning soil loss, this relationship can be defined by the following equation:

$$
\mathrm{SL}_{\mathrm{r}}=\mathrm{e}^{-\mathrm{bC}}
$$

where $\mathrm{SL}_{\mathrm{r}}=$ relative soil loss (or soil loss under a specific vegetation cover compared to the soil loss on a bare surface), $\mathrm{C}=$ vegetation cover $(\%)$ and $\mathrm{b}=\mathrm{a}$ constant which varies between 0.0235 and 0.0816 according to the type of vegetation and experimental conditions (Gyssels et al., 2005). Regarding to the runoff $\left(\mathrm{R}_{r}\right)$ for a wide range of vegetation types:

$$
\mathrm{R}_{\mathrm{r}}=\mathrm{e}^{-\mathrm{bC}}
$$

where $b$ values ranging from 0.0103 to 0.0843 according to the experimental conditions (Fig. 1).

In some cases, however, a linear decline in runoff volume has been described as vegetation cover increases (Branson and Owen, 1970; Kainz, 1989; Greene et al., 1994). Some variations in the classical negative trend of the cover-erosion function have also been reported by de Ploey et al. (1976), Morgan et al. (1996) and Rogers and Schumm (1991) under different specific experimental conditions, showing greater soil-loss rates as vegetation cover thickens, at least partially for a given range of covers.

The impact of herbaceous and woody crop production on soil erosion is crucial. Perennial grasses provide year-round soil cover, limiting erosion sometimes even with continued biomass harvest. Vigorous perennial herbaceous stands reduce water runoff and sediment loss and favour soil-development processes by improving soil organic matter, soil structure and soil water and nutrient-holding capacity. Minimum tillage management of row crops reduces erosion compared with systems involving more frequent or more extensive tillage. Woody crops reduce water erosion by improving water infiltration, reducing impacts by water droplets, intercepting rain and snow and physically stabilizing soil by their roots and leaf litter. Harvesting of woody plants may be followed by increased erosion. Forestry clear cutting, especially on steep slopes, often results in a large increase in water erosion.

In the semi-arid Mediterranean region, most experimental studies on the influence of the native vegetation on erosion have quantified soil loss and runoff under woodlands or shrublands comprising a mixture of plant species (Francis and Thornes, 1990; Romero Díaz et al., 1999; Durán et al., 2006a). All of these studies have concluded that typical Mediterranean shrubland vegetation is efficient in reducing water erosion, even under extreme torrential simulated rainfalls (González et al., 2004). In this context, Bochet et al. (2006) studied the influence of plant morphology and rainfall intensity on soil loss and runoff at the plant scale for three representative species: Rosmarinus officinalis, Anthyllis cytisoides and Stipa tenacissima of a semi-arid patchy shrubland vegetation in relation to bare soil in eastern Spain. The results indicate that the individual plants were valuable in interrill erosion control at the microscale, and the different plant morphologies and plant components explained the different erosive responses of these three species. Canopy cover played was key in reducing runoff and soil loss, and the litter cover beneath of plants was fundamental for erosion control during intense rainfall. In assessing the great potential of plant covers, it is therefore essential to consider its impact on soil protection.

\section{IMPACT OF EROSION ON SOIL PRODUCTIVITY}

The loss of soil from land surfaces by erosion is widespread globally and adversely impacts the productivity of all natural, agricultural, forest, and rangeland ecosystems, seriously decreasing water availability, energy, and biodiversity throughout the world. Future world populations will require everincreasing food supplies, considering that more than $99.7 \%$ of human food comes from the land (FAO, 1998), while less than $0.3 \%$ comes from the oceans and other aquatic ecosystems. Maintaining and augmenting the world food supply depends basically on the productivity and quality of all soils. Soil erosion and runoff reduce the soil productivity decreasing rainfall water infiltration, and water-storage capacity. In this sense, the effect of plant cover on soil represents a sustainable measure for improving productivity, given their many environmental benefits (Fig. 2). Since water is the prime limiting factor of productivity in all terrestrial ecosystems, when soil-water availability for agriculture is reduced, productivity is depressed. Particularly, in semiarid areas vegetation suffers longer periods of water deficit, determining the vegetation structure and complexity, and thus soil protection and water conservation. During precipitation, some water is intercepted by the plant covers, and a new spatial distribution of rainfall takes place due to the throughfall and stem-flow pathways 
(Bellot and Encarré, 1998). In this context, the type of plant community buffers the kinetic energy of rainfall before the water reaches the soil (Brandt and Thornes, 1987; Durán et al., 2004a).

\subsection{Climate and soil erosion}

Recent studies suggest that climatic variability will increase as a consequence of global warming, resulting in greater frequency and intensity of extreme weather events, which will inevitably intensify erosion (Nunes and Seixas, 2003; Nearing et al., 2005). This trend could be especially threatening in Mediterranean areas highly susceptible to soil erosion, where precipitation is characterized by scarcity, torrential storms and extreme variability in space and time (Romero et al., 1998). Flash storms are common throughout the Mediterranean area, and they have very short return periods (de Luis, 2000). Several researchers have pointed out that this irregularity of precipitation is the main cause for temporal irregularity of erosion rates in Mediterranean landscapes (Zanchi, 1988; Renschler et al., 1999; Renschler and Harbor, 2002). Also, no exact relation has been found between extreme rainfall and extreme fluvial discharge (Osterkamp and Friedman, 2000; Nunes et al., 2005), and largest rainfall events do not necessarily produce the maximum soil erosion (González et al., 2004; Romero et al., 1999). On the other hand, according to Marques et al. (2007), the erosive power of a single light rainfall event of $20.8 \mathrm{~mm} \mathrm{~h}^{-1}$ with kinetic energy of $13.5 \mathrm{~J} \mathrm{~m}^{-2} \mathrm{~mm}^{-1}$ is negligible when plots are covered with natural vegetation. Moreover, in addition to the Mediterranean rainfall being highly variable in space, soil and plant cover is extremely diverse and, as a consequence, erosion rates display great spatial variation. In any case, quantification of magnitudes of daily soil eroded can be affected by field methods. All these factors explain the extreme disparity of erosion amounts reported at different times and in different places and highlight the difficulty presented by extrapolating data obtained from experimental plots (Roels, 1985; Stroosnijder, 2005).

Although soil erosion varies from site to site, and from year to year, the annual amount of soil eroded depends on a few daily erosive events. Each year scattered daily erosive events represent more than $50 \%$ of annual soil eroded, regardless of the total amount.

\subsection{Soil seal and crust development}

Surface crusts and seals can form from a variety of processes, both physical and biological, and have the potential to alter runoff and erosion, especially in regions with low plant covers. Despite the obvious links between seals and crusts, these features have rarely been considered together. Many soils, especially those in semiarid regions, develop compacted surface layers that are denser and have lower porosities than the materials immediately below them (Valentin and Bresson, 1992). These layers, known as "seals" when wet and "crusts" when dry, are generally no more than a few millimeters thick and form through the interaction of several, often interrelated, processes (Bradford et al., 1987; Singer and Shainberg, 2004). Most commonly, crusts and seals are described as having a physicochemical origin in which soil aggregates are initially broken down by raindrop impacts and/or slaking processes. The dispersed particles are subsequently deposited within and clog soil pore spaces, creating a low-permeability layer at the surface (Assouline, 2004). As the seals dry to form crusts, clays can also act to bind particles together, reinforcing the persistence of the crusted layer (Shainberg, 1992). However, crusts and seals can form in a variety of other ways, including through the compaction of soils by raindrop impacts, from the erosion of coarse surface layers by runoff, through the deposition of fine particles brought in by overland flows, from clay swelling at the soil surface (Valentin, 1991), and from biological organisms (such as fungal hyphae) binding soil particles together (Greene et al., 1990).

Despite the large array of possible formative processes, physical (or nonbiological) crusts and seals are commonly classified as either structural or depositional features (West et al., 1992). Structural seals and crusts form in association with rain falling directly on soils and typically require raindrop impact to develop (Fox et al., 2004). Depositional seals and crusts, however, result from the lateral redistribution of sediment by runoff, and do not require soils to be directly exposed to rainfall (Assouline, 2004). Once formed, sealed soils generally have lower hydraulic conductivities and infiltration rates and have higher shear strengths than unsealed soils although this very much depends on the type of seal in place. These conditions combine to increase runoff and influence local erosion processes (McIntyre, 1958; Assouline, 2004).

Almost all of the existing research into seal and crust formation has been undertaken on soils that have been extracted, physically and theoretically, from their surrounding environments (Diekkruger and Bork, 1994; Fox and Bissonnais, 1998; Mills and Fey, 2004). Therefore, the loss of vegetation covers from soil increases the development of surface crusts and seals, and consequently increases soil erosion and runoff.

\subsection{Carbon losses from soils}

Soil degradation is one of the greatest environmental problems in the world. In semiarid Mediterranean areas the dry climate leads to a low level of plant cover which, in turn, leads to very scarce organic-matter input, and, consequently, to a poor soil-structure development (Díaz et al., 1994). Under these conditions the role of plant covers in protecting soil against erosion is crucial, since the removal of vegetation strongly increases surface runoff and sediment yield and, as a result, soil quality deteriorates (Kaihura et al., 1999).

Vegetation removal is normally followed by a period in which the soil has sufficient organic matter to maintain its physical-chemical properties, enabling it to recover from the damage, according to the concept of soil resilience (Castillo et al., 1997; Durán et al., 2006a). Soils rich in organic matter, such as those of many rainy regions, are more resilient than soils with low organic-matter content, such as those which 


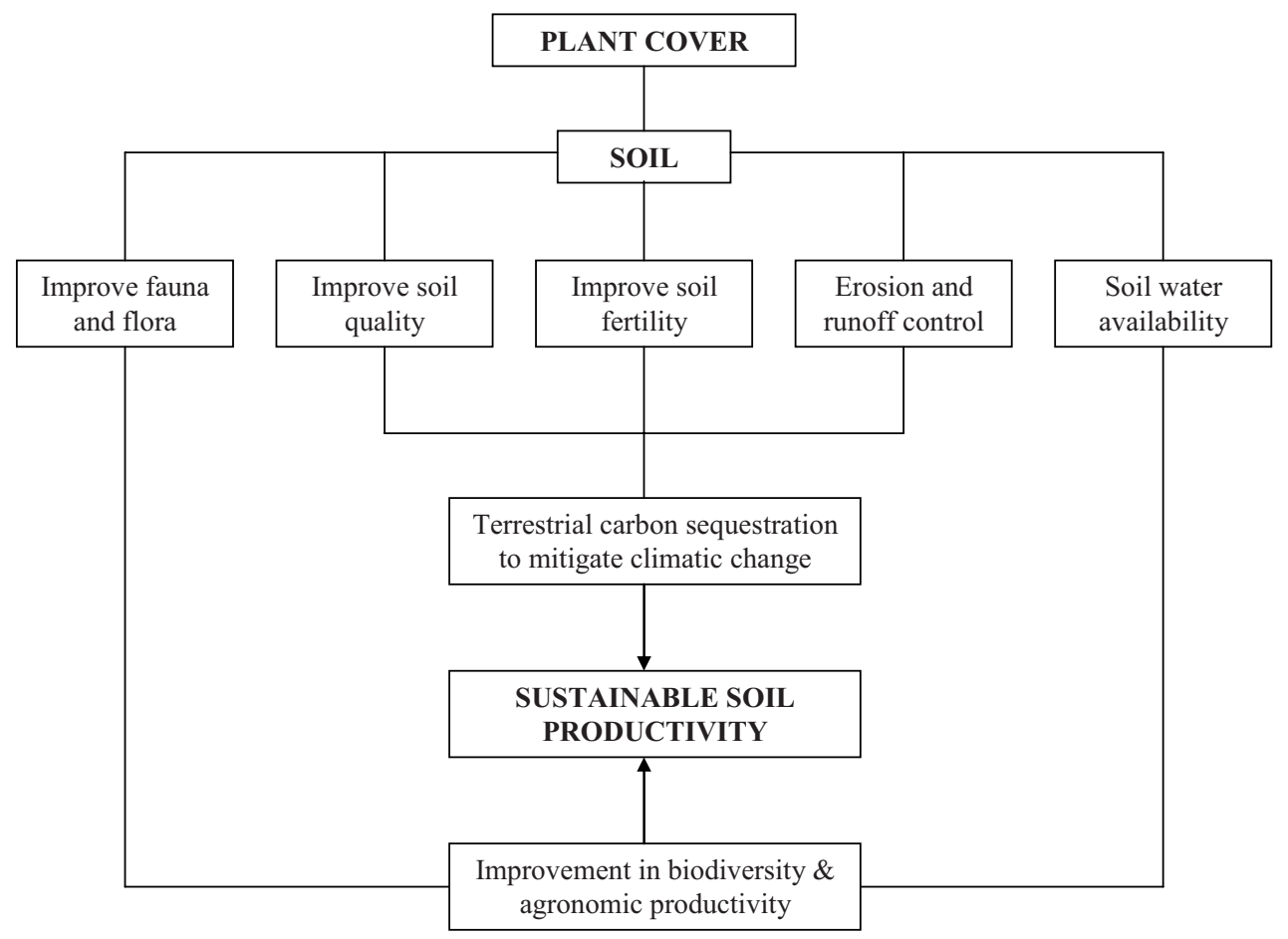

Figure 2. Soil protection by plant cover for sustainable soil productivity.

predominate in arid and semiarid areas. In the latter case, when the surface layer, which contains fresh plant remains, is eroded, the subsurface material is exposed and the capacity of this material to hold nutrients becomes crucial (Gregorich et al., 1998).

Although there is general agreement with regard to the role of erosion in soil organic carbon losses, some controversy persists with respect to the intensity of soil organic carbon losses caused by mineralization. According to Martínez-Mena et al. (2002), the mineralization process was found to be much more influential than erosion in the soil organic carbon losses recorded during the 9 years following vegetation removal in a semiarid Mediterranean soil. In the first 6 years, rapid mineralization was the main cause of the soil organic carbon decreases measured; while in the next 3 years the soil organic carbon losses were due mainly to erosion. Vegetation removal led to a progressive enrichment of the sediments in organic carbon and nitrogen with time. These results reflect the importance of preserving the plant cover in semiarid areas, where it is crucial for maintaining the soil organic-carbon stock. In this sense, Yaalon (1990) indicated that mineralization would lead to a reduction in the soil organic-matter content within 50 years in the Mediterranean area. On the contrary, Squires et al. (1998) pointed out that the carbon stored in dryland soils is a very substantial deposit, since it has been stabilized over a period of hundreds to thousands of years. Scharpenseel and Pfeiffer et al. (1998) indicated that these areas may be very sensitive to climatic change due to inadequate reserves of water and soil nutrients. Therefore, the vulnerability of Mediterranean arid and semiarid lands to human-induced changes in soil use means that the effects of climate change upon these environments will be exacerbated.

Reduced precipitation or increased temperature accelerates land degradation through the loss of plant cover, biomass turnover, nutrient cycling and soil organic-carbon storage, accompanied by higher greenhouse emissions (Ojima et al., 1995). An understanding of the dynamics of soil organic carbon is required to appreciate fully the ability of soils to stabilize carbon and its implications for global change (Bajracharya et al., 1998).

It is well-know that water erosion selectively removes the fine organic particles from the soil, leaving behind large particles and stones. Fertile soils frequently contain about 100 tons of organic matter per hectare (or $4 \%$ of the total soil weight) (Young, 1990). Because most of the organic matter is close to the soil surface in the form of decaying leaves and stems, erosion of the topsoil significantly decreases soil organic matter. Several studies have demonstrated that the soil removed by either wind or water erosion is 1.3-5.0 times richer in organic matter than the soil left behind (Barrows and Kilmer, 1963).

Soil organic matter facilitates the formation of soil aggregates and increases soil porosity. In this way, it improves soil structure, which in turn facilitates water infiltration and ultimately the overall productivity of the soil (Chaney and Swift, 1984; Langdale et al., 1992). In addition, organic matter aids cation exchange, enhances root growth, and stimulates the increase of important soil biota. About $95 \%$ of the soil nitrogen and $25 \%-50 \%$ of the phosphorus are contained in the organic matter.

Once the organic matter layer is depleted, the productivity of the ecosystem, as measured by crop-plant yields, declines 
both because of the degraded soil structure and the depletion of nutrients contained in the organic matter. Soils that suffer severe erosion may produce 15\%-30\% lower crop yields than un-eroded soils (Schertz et al., 1989; Langdale et al., 1992).

The main losses of $\mathrm{C}$ from soil is in the form of $\mathrm{CO}_{2}$ from $\mathrm{OM}$ mineralisation although fires cause direct $\mathrm{C}$ emissions to the atmosphere and changes species composition of the vegetation (Harden et al., 2000), altering the dynamics of terrestrial $\mathrm{C}$ stores for subsequent decades. The gaseous $\mathrm{C}$ efflux from soils depends initially on the rate of $\mathrm{CO}_{2}\left(\right.$ or $\left.\mathrm{CH}_{4}\right)$ production within the soil-plant root system, and subsequently on the rate of gaseous diffusion and mass flow from soil waters to the atmosphere; a function of soil moisture and textural properties (Skiba and Cresser, 1991).

Increased $\mathrm{C}$ sequestration in soils, as a way to reduce atmospheric $\mathrm{CO}_{2}$ concentrations, was first proposed in 1977 (Dixon et al., 1994). One appropriate option is to restore a proportion of the $\mathrm{C}$ historically lost from soils that have previously been depleted in $\mathrm{C}$, such as agricultural and degraded soils (Smith, 2001a, b), e.g. revegetation of abandoned arable land may increase soil C by $0.3-0.6 \times 10^{3} \mathrm{~kg} \mathrm{C} \mathrm{ha}^{-1} \mathrm{yr}^{-1}$. In order to maximize $\mathrm{C}$ sequestration, knowledge of factors such as erosion and the translocation of soil across the landscape also need to be considered (Van Oost et al., 2005) particularly regarding agricultural land, where tillage and erosion are strongly related. At present, most grasslands are believed to be $\mathrm{C}$ sinks, with an estimated $0.03-1.1 \times 10^{3} \mathrm{~kg} \mathrm{C} \mathrm{ha}^{-1} \mathrm{yr}^{-1}$ as $\mathrm{C}$ sequestration is strongly influenced by the productivity and management of the ecosystems (Soussana et al., 2004) although grassland-derived soils do tend to have higher base saturation, enhancing aggregation and increased capability to sequester C (Collins et al., 2000).

The sheet erosion is flow over vegetated surfaces while channel erosion is limited to where soils lack plant cover. This overland flow occurs, removing topsoil and hence substantial OM translocation, when runoff is greater than the soilinfiltration capacity. Carbon and nutrients from water-eroded soil is relocated downslope from one area to another or transported to surface waters (Stallard, 1998; Smith et al., 2001b; Liu et al., 2003; Rodríguez et al., 2007a). The amount of C mobilized by erosion processes has been estimated at 0.20 $0.76 \times 10^{12} \mathrm{~g} \mathrm{C} \mathrm{yr}^{-1}$, of which $0.08-0.29 \times 10^{12} \mathrm{~g} \mathrm{C} \mathrm{yr}^{-1}$ was re-deposited and $0.12-0.46 \times 10^{12} \mathrm{~g} \mathrm{C} \mathrm{yr}^{-1}$ was transported to surface waters (Quinton et al., 2006). Rodríguez et al. (2007a), in south-eastern Spain reported the SOC losses about $12.2 \mathrm{~g} \mathrm{C} \mathrm{m}^{-2}$ from the taluses of orchard terraces without plant covers.

\section{LAND USE AND SOIL EROSION}

The main problems for soils in the European Union are irreversible losses due to increasing soil sealing and soil erosion, and continuing deterioration due to local and diffuse contamination. It is envisaged that Europe's soil resource will continue to deteriorate, as a result of changes in climate, land use and other human activities.
Soil erosion, in particular, is regarded as one of the major and most widespread forms of land degradation, and, as such, poses severe limitations to sustainable agricultural land use. Erosion reduces on-farm soil productivity and contributes to water-quality problems from the accumulation of sediments and agro-chemicals in waterways.

Prolonged erosion causes irreversible soil loss over time, reducing the ecological functions of soil: mainly biomass production, crop yields due to removal of nutrients for plant growth, and reduction in soil-filtering capacity due to disturbance of the hydrological cycle (from precipitation to runoff).

Soil losses are high in southern Europe, but soil erosion due to water is becoming an increasing problem in other parts of Europe. Table I shows some of the findings regarding to the area affected by soil degradation in Europe (Gobin et al., 2003).

The Mediterranean region is considered to be particularly prone to erosion. This is because it is subject to long dry periods followed by heavy bursts of intensive rainfall, falling on steep slopes with fragile soils and low plant cover. According to the EEA (2001), soil erosion in north-western Europe is considered to be slight because rain is falling mainly on gentle slopes, is evenly distributed throughout the year and events are less intensive. Consequently, the area affected by erosion in northern Europe is much more restricted in its extent than in southern Europe.

In parts of the Mediterranean region, erosion has reached a stage of irreversibility and in some places erosion has practically ceased because there is no more soil left. In the most extreme cases, soil erosion leads to desertification. With a very slow rate of soil formation, any soil loss of more than $1 \mathrm{Mg} \mathrm{ha}^{-1} \mathrm{yr}^{-1}$ can be considered as irreversible within a time span of 50-100 years.

Losses of 20 to $40 \mathrm{Mg} \mathrm{ha}^{-1}$ in individual storms, which may happen once every two or three years, are measured regularly in Europe with losses of more than $100 \mathrm{Mg} \mathrm{ha}^{-1}$ in extreme events (Morgan, 1992).

Attention is focused mainly on rill- and interrill erosion because this type of erosion affects the largest area. Other forms of erosion are also important - for example, gully erosion, landslides and, to a lesser extent, wind erosion.

The rate of soil degradation is depends upon the rate of land-cover degradation, which in turn is influenced by both adverse climatic conditions and land-use management changes. Plant cover, type of land use, and intensity of land use are clearly key factors controlling the intensity and the frequency of overland flow and surface erosion. Vegetation cover may be altered radically by human activity within a short time, but physical and biological changes within the soil, affecting erosion rates, may take longer periods. The type of land use and land-use intensity is affected by various environmental and socio-economic factors; therefore indicators for soil erosionrisk assessment should be related to these factors. 
Table I. Extend of human-induced soil degradation by erosion in Europe (million hectares) ${ }^{1}$.

\begin{tabular}{lllllll}
\hline & Erosion type & Light & Moderate & High & Extreme & Total \\
\hline Accession countries & Water erosion & 4.5 & 29.2 & 14.7 & 0.0 & 48.4 \\
& Wind erosion & 0.0 & 0.0 & 0.0 & 0.0 & 0.0 \\
& AC total & 4.5 & 29.2 & 14.7 & 0.0 & 48.4 \\
EFTA countries & Water erosion & 0.8 & 1.5 & 0.0 & 0.0 & 2.3 \\
& Wind erosion & 0.6 & 1.3 & 0.0 & 0.0 & 1.9 \\
& EF total & 1.3 & 2.9 & 0.0 & 0.0 & 4.2 \\
Rest of Europe & Water erosion & 0.8 & 19.3 & 6.5 & 1.0 & 27.7 \\
& Wind erosion & 0.0 & 5.8 & 0.0 & 0.7 & 6.5 \\
European Union & ER total & 0.8 & 25.1 & 6.5 & 1.7 & 34.2 \\
& Water erosion & 12.8 & 11.9 & 1.4 & 0.0 & 26.2 \\
& Wind erosion & 1.0 & 0.1 & 0.0 & 0.0 & 1.1 \\
Europe (excl. the Russian Federation) & EU total & 13.8 & 12.0 & 1.4 & 0.0 & 27.3 \\
& Water erosion & 18.9 & 62.0 & 22.6 & 1.1 & 104.6 \\
& Wind erosion & 1.6 & 7.2 & 0.0 & 0.7 & 9.5 \\
& AC total & 20.5 & 69.2 & 22.6 & 1.8 & $114.1 *$ \\
\hline
\end{tabular}

${ }^{1}$ Gobin et al. (2003); *17.4\% of total land area.

Note: Any mismatch between totals and disaggregated figures is due to the rounding process.

Source: EEA (Oldeman et al., 1991; Van Lynden, 1995; data: Glasod, UNEP and ISRIC-UNEP/GRID).

\subsection{Soil loss in agricultural lands}

Approximately $50 \%$ of the earth's land surface is devoted to agriculture; of this, about one-third is planted with crops and two-thirds dedicated to grazing lands (WRI, 1997; USDA, 2001). Cropland is more susceptible to erosion because of frequent cultivation of the soils and the vegetation is often removed before crops are planted. In addition, cropland is often left without vegetation between plantings, intensifying erosion on agricultural land, which is greater than erosion in natural forest areas.

According to Pimentel et al. (1995), worldwide erosion on agricultural lands averages about $30 \mathrm{Mg} \mathrm{ha}^{-1} \mathrm{yr}^{-1}$ and ranges from 0.5 to $400 \mathrm{Mg} \mathrm{ha}^{-1} \mathrm{yr}^{-1}$. As a result of soil erosion, during the last 40 years about $30 \%$ of the world's arable land has become unproductive and, much of that has been abandoned for agricultural use (Kendall and Pimentel, 1994). Each year an estimated 10 million ha of cropland worldwide are abandoned due to lack of productivity caused by soil erosion (Faeth and Crosson, 1994). On the other hand, extensive Mediterranean areas cultivated with rainfed crops are mainly restricted to hilly lands with shallow soils, very sensitive to erosion. In this context, Extensive areas cultivated with rainfed crops (i.e. vines, almonds and olives) are mainly confined to hilly lands with shallow soils which are very prone to erosion under traditional soil-management systems (Francia et al., 2006; Martínez et al., 2006; Durán et al., 2007) but erosion can be significantly reduced by the use of plant strips running across the hillslope (Tab. II) especially with aromatic and medicinal plants (Fig. 3). García et al. (1995) pointed out that the cereal cultivation in steep slopes encourages soil erosion, especially under non-conservative systems, and the change of cereals into meadows represents an improvement of the hydrological functioning, which reaches its most positive values with colonization by a dense shrub cover. Otherwise, these areas become vulnerable to soil erosion because of the decreased protection by vegetation cover in reducing effective rainfall intensity at the ground surface. Almonds and vines require frequent removal of perennial vegetation using herbicides or by tillage. In fact, soils under these crops remain almost bare during the whole year, creating favourable conditions for overland flow and soil erosion. Erosion data measured along the northern Mediterranean region and the Atlantic coastline located in Portugal, Spain, France, Italy and Greece in a variety of landscapes and under a number of land uses representative of the Mediterranean region (rainfed cereals, vines, olives, Eucalyptus groves, shrubland) showed that the greatest rates of runoff and sediment loss were measured in hilly areas under vines i.e. in south-eastern France $34 \mathrm{Mg} \mathrm{ha}^{-1}$ (Wainwright, 1996), in Spain $282 \mathrm{Mg} \mathrm{ha}^{-1}$ (Martínez-Casasnovas et al., 2005). Areas cultivated with wheat are sensitive to erosion, especially during winter, generating intermediate amounts of runoff and sediment loss especially under rainfalls higher than $380 \mathrm{~mm}$ per year. Olives grown under semi-natural conditions, particularly where there is an understorey of annual plants greatly restrict soil loss to negligible values. Erosion in shrublands increased with decreasing annual rainfall to values in the range of $280-300 \mathrm{~mm}$, and then decreased as rainfall decreased further.

Rainfall amount and distribution are the major determinants of cereal biomass production (Kosmas et al., 1993). These areas become vulnerable to erosion because of the decreased protection by vegetation cover in reducing effective rainfall intensity at the ground surface (Faulkner, 1990), the reduction of infiltration rate due to compaction from farm machinery, and the formation of a soil surface crust (Morin and Benyamini, 1977).

Land-use changes affecting many mountains in the world have serious consequences on runoff and sediment yield and are probably the most important factor in controlling soil conservation and sustainability. For instance, the traditional 
Table II. Average soil-erosion and runoff prevention by plant strips in semiarid slopes with olive and almond orchards under 30 and $35 \%$ slope, respectively.

\begin{tabular}{lllll}
\hline $\begin{array}{l}\text { Soil-management } \\
\text { system }\end{array}$ & \multicolumn{2}{c}{ Olive orchards } & \multicolumn{2}{c}{ Almond orchards } \\
\cline { 2 - 5 } & $\begin{array}{l}\text { Erosion } \\
\left(\mathrm{Mg} \mathrm{ha}^{-1} \mathrm{yr}^{-1}\right)\end{array}$ & $\begin{array}{l}\text { Runoff } \\
\left(\mathrm{mm} \mathrm{yr}^{-1}\right)\end{array}$ & $\begin{array}{l}\text { Erosion } \\
\left(\mathrm{Mg} \mathrm{ha}^{-1} \mathrm{yr}^{-1}\right)\end{array}$ & $\begin{array}{l}\text { Runoff } \\
\left(\mathrm{mm} \mathrm{yr}^{-1}\right)\end{array}$ \\
NT & 25.6 & 39.0 & n.a. & n.a. \\
CT & 5.70 & 10.9 & 10.5 & 58.1 \\
BS & 2.10 & 19.8 & 1.66 & 23.8 \\
NVS & 7.1 & 8.6 & n.a. & n.a. \\
LS & n.a. & n.a. & 5.18 & 47.8 \\
TS & n.a. & n.a. & 0.50 & 26.1 \\
SS & n.a. & n.a. & 2.10 & 31.5 \\
RS & n.a. & n.a. & 0.60 & 23.2 \\
\hline
\end{tabular}

NT, non-tillage without plant strips; CT, conventional tillage; BS, non-tillage with barley strips; NVS, non-tillage with native vegetation strips; LS, lentil strips; TS, thyme strips; SS, salvia strips; RS, rosemary strips; n.a., not available.
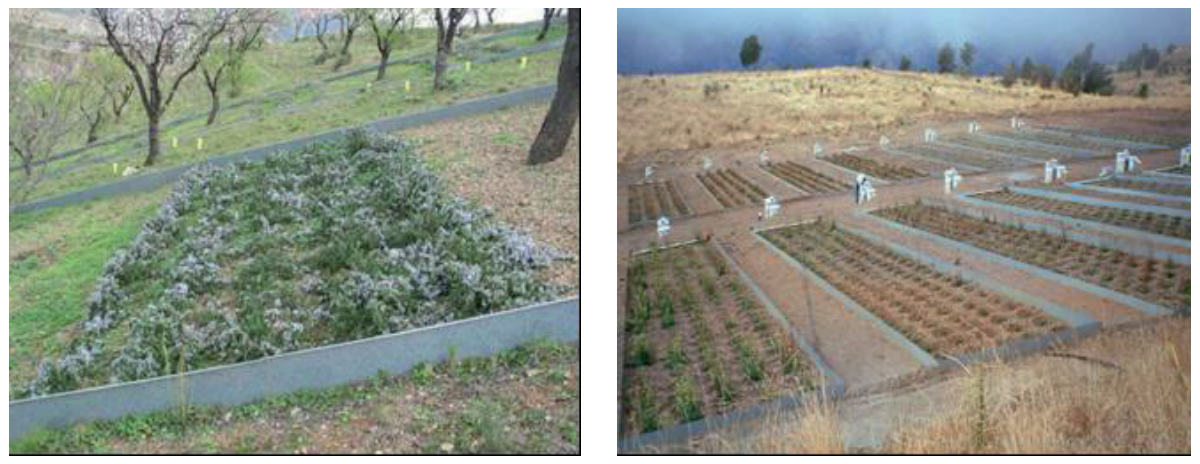

Figure 3. Thyme strips used for erosion control in semiarid slopes under almond orchards and plots used for study the harvest intensity of biomass from cultivated sage (Salvia lavandulifolia V.), oregano (Origanum bastetanum L.), santolina (Santolina rosmarinifolia L.), and lavender (Lavandula lanata L.).

system of cereal cultivation (i.e. shifting agriculture) was very extensive in past centuries on steep sunny hillslopes. Nowadays the hillslopes cultivated in the past by means of shifting agriculture are characterized by an open submediterreanean shrub on a very thin and stony soil, testimony of intense soil loss. The consequences of fertilizing the cereal fields can be observed several years later not only by the solute outputs by runoff, but also by the quick plant colonization after farmland abandonment.

\subsection{Shrub and forest lands}

The Mediterranean basin has seen the development of some of the world's oldest civilizations, spreading agriculture and livestock while using trees for building and fuel being these areas has long been exploited and as a result the tree cover is drastically reduced in Mediterranean countries (Le Houerou, 1981; Thirgood, 1981; Blondel and Aronson, 1999). About the $9-10 \%$ of the Mediterranean area is currently forested, and in the Iberian Peninsula only $0.2 \%$ can be considered natural or seminatural forests (Marchand, 1990). Simultaneously, the surface area covered by shrublands has increased, representing stages of degradation of mature forests as well as stages of vegetation recovery in abandoned agricultural lands (di Castri,
1981; Grove and Rackham, 2001). In both cases, local and regional characteristics, such as resource availability or the lack of tree propagules, act as barriers to succession (Pickett et al., 2001) and result in self-perpetuating systems that hardly return to the structure and complexity of the original mature community (Blondel and Aronson, 1999).

Several hilly areas under natural forests around the Mediterranean region have been reforested with exotic species such as Eucalyptus. Such soils are undergoing intense erosion as compared with soils left under natural vegetation. However, the measured rates of erosion under Eucalyptus are relatively lower than those measured under vines, almonds and cereals.

Soil-erosion data measured from various types of vegetation and certain physiographic conditions showed that the best protection from erosion was measured in areas with a dominant vegetation of evergreen oaks, pines and olive trees under semi-natural condition.

Pines have a lower ability to protect the soils in southern aspects due to the higher rate of litter decomposition and the restricted growth of understorey vegetation. Deciduous oak trees offer relatively low protection from erosion in cases where the falling leaves do not cover the whole soil surface.

The main factors affecting the evolution of the Mediterranean vegetation, in the long term, are related to the irregular 
and often inadequate water supply, the long period of the dry season, and in some cases fire and overgrazing. According to the types of leaf generation, the following two major groups of vegetation can be distinguished: (a) deciduous: drought avoiding with a large photosynthetic capacity but no resistance to desiccation; and (b) evergreen (sclerophyllous): drought enduring with low rates of photosynthesis. The main response of the plants to increased aridity is the reduction in leaf-area index. Severe droughts that cause a reduction in leaf-area index may be beneficial in the short term as plant transpiration is reduced, but such drought will increase the probability of enhanced soil erosion when rain eventually falls, as protective vegetation cover is reduced.

The various ecosystems present in the Mediterranean region have a great capacity of adaptation and resistance to aridity, as have most of the species, to survive under Mediterranean climatic conditions. For many months, plants may have to endure soil-moisture contents below the theoretical wilting point. Most probably the expected changes in the vegetation performance, resulting from a gradual precipitation decrease, would only be noticed after a critical minimum number of years.

In stable forest ecosystems, where soil is protected by vegetation, erosion rates are relatively low, ranging from only 0.004 to $0.05 \mathrm{Mg} \mathrm{ha}^{-1} \mathrm{yr}^{-1}$ (Roose, 1988). Tree leaves and branches intercept and diminish rain and wind energy, while the leaves and branches cover the soil under the trees to protect the soil further. However, this changes dramatically when forests are cleared for crop production or pasture.

Vacca et al. (2000) has estimated runoff coefficients of $0.65-1.59 \%$, and erosion rates between 0.03 and $0.05 \mathrm{Mg} \mathrm{ha}^{-1}$ in plots of $20 \mathrm{~m}^{2}$ covered by herbaceous plants and shrubs, while in Eucalyptus sp. plots (15 years old and 25\% vegetation cover) the estimated rates were $2.01 \%$ and $0.19 \mathrm{Mg} \mathrm{ha}^{-1}$, respectively. Romero et al. (1988) calculated annual soil losses of $0.08-2.55 \mathrm{Mg} \mathrm{ha}^{-1} \mathrm{yr}^{-1}$ in a catchment with $35 \%$ of vegetation cover. In a microcatchment with $60 \%$ of vegetation cover, Albadalejo and Stocking (1989) determined rates between 0.5 and $1.2 \mathrm{Mg} \mathrm{ha}^{-1} \mathrm{yr}^{-1}$, and López et al. (1991) reported annual losses of $0.1 \mathrm{Mg} \mathrm{ha}^{-1} \mathrm{yr}^{-1}$ in plots with $80 \%$ shrub cover. Areas with reduced plant cover (lower than $50 \%$ ) caused by human interference or affected by wildfires can increase soil loss in the first years after disturbance (Soto and Díaz, 1997). According to Durán et al. (2004a), on a hillslope with $35.5 \%$ of slope under Rosmarinus officinalis cover runoff ranged from 7.9 to $1.3 \mathrm{~mm} \mathrm{yr}^{-1}$ and erosion from 0.16 to $0.002 \mathrm{Mg} \mathrm{ha}^{-1} \mathrm{yr}^{-1}$, while under native vegetation, runoff ranged 4.4 to $0.9 \mathrm{~mm} \mathrm{yr}^{-1}$ and erosion from 0.32 to $0.002 \mathrm{Mg} \mathrm{ha}^{-1} \mathrm{yr}^{-1}$. Chirino et al. (2006) measured the erosion rates with different plant cover types: dry grassland formations with dwarf scrubs (Brachypodium retusum, Anthyllis cytisoides L., Helianthemum syriacum, and Thymus vulgaris L.) with $0.049 \mathrm{Mg} \mathrm{ha}^{-1} \mathrm{yr}^{-1}$; under landscape patches composed of scattered thorn and sclerophyllous shrublands (Quercus coccifera L., Pistacia lentiscus L., Erica multiflora L., Rhamnus lyciodes L. and Rosmarinus officinalis L.) $0.042 \mathrm{Mg} \mathrm{ha}^{-1} \mathrm{yr}^{-1}$; afforested dry grasslands $0.035 \mathrm{Mg} \mathrm{ha}^{-1} \mathrm{yr}^{-1}$, and finally afforested thorn

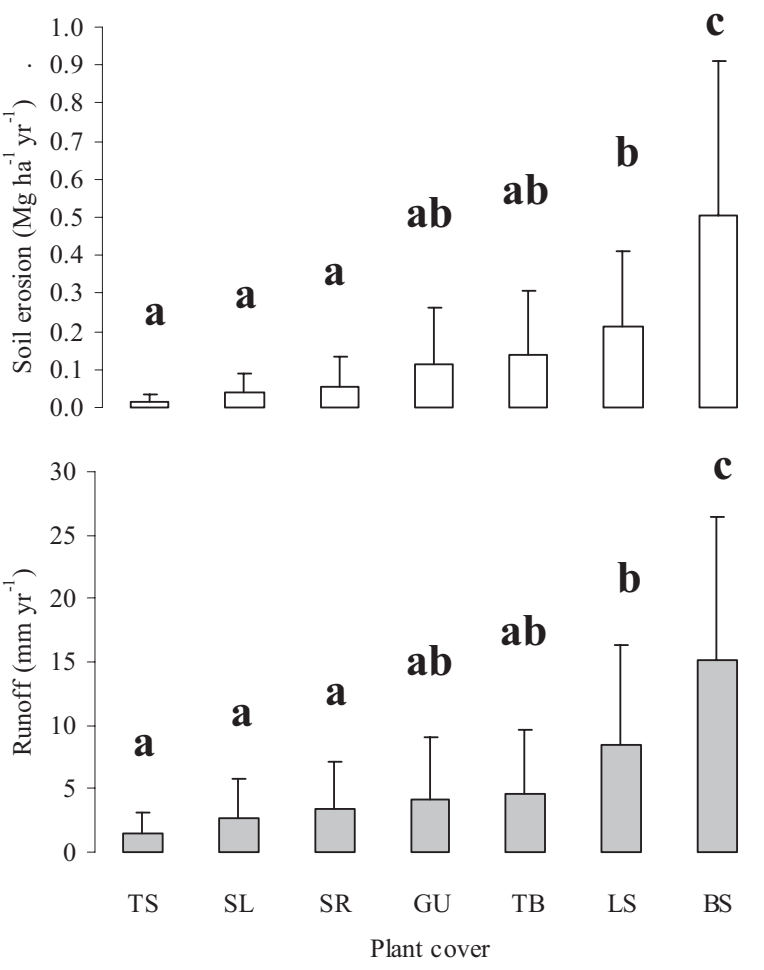

Figure 4. Mean soil erosion and runoff for each plant cover and bare soil. Columns with different letters are statistically different al level 0.01 (LSD). TS, Thymus serpylloides; SR, Santolina rosmarinifolia; SL, Salvia lavandulifolia; GU, Genista umbellate; TB, Thymus baeticus; LS, Lavandula stoechas. Vertical bars represent Standard deviation $(\mathrm{n}=24)$.

shrublands of $0.019 \mathrm{Mg} \mathrm{ha}^{-1} \mathrm{yr}^{-1}$. By contrast, the rate of bare soil had a runoff coefficient and soil loss of $4.42 \%$ and $1.90 \mathrm{Mg} \mathrm{ha}^{-1} \mathrm{yr}^{-1}$, respectively (Chirino et al., 2006). In this context, for hilly areas with $13 \%$ of slope in SE Spain and bare soil the runoff ranged from 154 to $210 \mathrm{~mm}$ and erosion from 4.5 to $7.8 \mathrm{Mg} \mathrm{ha}^{-1} \mathrm{yr}^{-1}$, differing significantly from those protected with plant covers of aromatic and medicinal plants (Fig. 4) (Durán et al., 2006a).

The inappropriate wild harvest of aromatic plants by uprooting in mountainous areas endangers the soil conservation, and there is an urgent need to implement appropriate land management. Over a four-year period, soil erosion and runoff were monitored in erosion plots in Lanjarón (Granada, SE Spain) on the southern flank of the Sierra Nevada Mountains, comparing four harvest intensities of four aromatic shrubs (Lavandula lanata L., Santolina rosmarinifolia L. Origanum bastetanum, and Salvia lavandulifolia V.): $0 \%$ (HI-0), 25\% (HI-25), 50\% (HI-50), and 75\% (HI-75). The average soil loss for HI- 0 , HI-25, HI-50, and HI-75 during the study period was $144.6,187.2,256.0$, and $356.0 \mathrm{~kg} \mathrm{ha}^{-1}$, respectively, and runoff 2.6, 3.2, 3.4, and $4.7 \mathrm{~mm}$, respectively (Fig. 5). Since no significant differences were found between HI-25 and HI-50 for soil erosion and runoff, and harvest and distillation of wild aromatic plants currently persists as an important economic activity in mountainous areas of the study zone, this study 


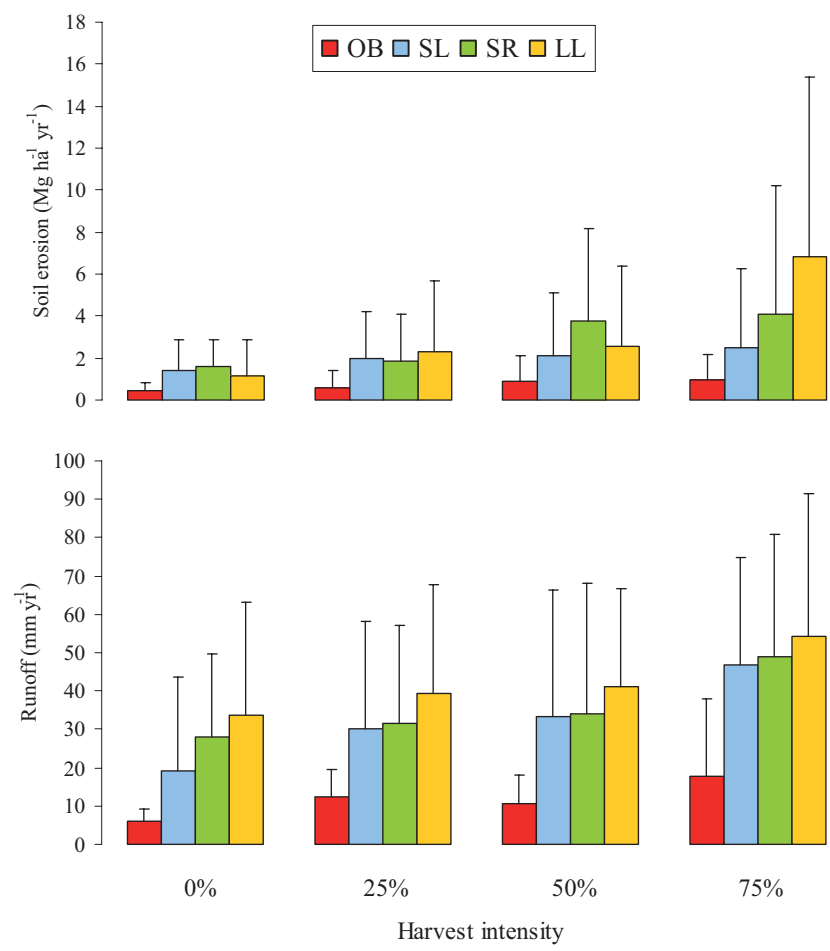

Figure 5. Mean annual soil erosion and runoff for each harvest intensity and plant cover. OB, Origanum bastetanum; SL, Salvia lavandulifolia; SR, Santolina rosmarinifolia; LL, Lavandula lanata. Vertical bars represent Standard deviation $(n=4)$.

demonstrated that the cultivation of aromatic shrubby plants (even when removing $50 \%$ of the above ground biomass) protected the soil from rain erosivity and produced reasonable essential-oil yields Consequently, the rational harvest of cultivated aromatic and medicinal herbs in semiarid slopes not only protect the soil against erosion and improved soil quality but also made sustainable agriculture possible in mountain areas.

\subsection{Impact of erosion in the Mediterranean terraced lands}

The need for terracing as a soil-conservation technique on sloping land has been emphasized. In much of the steeply sloping lands of Mediterranean basin, terracing was introduced in a bid to control soil erosion (Durán et al., 2005; Abu Hammad et al., 2006). Most of the terraces commonly develop a systematic variation in crop production showing a low yield on the upper part, which progressively increases down the lower sections of terrace. This uneven terrace productivity, which is observed for all crops, is hypothesised to be mainly a result of hoeing down the slope perpendicular to the contour, which is ergonomical but gradually causes scouring of the topsoil on the upper parts of the terrace which is then deposited in the lower parts.

An important land use change recorded in the Mediterranean basin comprises the abandonment of agricultural lands due to economic and social changes, which is followed by significant impacts on soil erosion. Observed land abandonment may have positive or negative impacts on soil protection from erosion because fundamental ecosystem processes are influenced by changes in agricultural practices and soilresource management. Olive and almond orchards comprise typical examples of traditional, extensive cultivation, which is abandoned. The olive groves are spread on marginal areas and located mainly on sloping terraced lands with low-productivity soils.

In these areas with high erosion risk, land abandonment is followed by natural vegetation regeneration, resulting in decreased soil erosion (Grove and Rackham, 2001). According to theory as shrub vegetation is filling in, protection of soil resources is increasing while soil erosion is decreasing (Elwell and Stocking, 1976; Morgan, 1996). Also, after abandonment, soil properties such as organic-matter content, soil structure, and infiltration rate improve, resulting to more effective soil protection to erosion (Trimble, 1990; Kosmas et al., 2000). However, simultaneous stopping of traditional land management practices results in soil erosion increase (Morgan and Rickson, 1990). Specifically, on sloping lands, an important abandonment of conservation practices, which are applied on traditional drystone terraces, is recorded. According to Koulouri and Giourga (2006) the abandonment of traditional extensive cultivation in the Mediterranean basin has different impacts on soil erosion which closely related to slope gradient. That is, when the slope is steep (25\%), soil erosion increases significantly because the dense protective cover of annual plants decrease and shrubs' vegetation cover increases, and if the slope gradient is very steep (40\%), soil erosion remains at the same high levels after cultivation abandonment. And the drystone terraces play an important role by supporting soil material and collapse from runoff water.

On the other hand, the study was carried out in Almuñécar (SE Spain) addressing the impact of erosion in the taluses of orchard terraces. The farmers in this zone construct bench terraces primarily to use the steeply sloping lands for agriculture, and to reduce soil erosion (Fig. 6). Today, on these steep terraces, intensive irrigated agriculture has established subtropical crops, including avocado (Persea americana Mill.), mango (Mangifera indica L.), loquat (Eriobotrya japonica L.), custard apple (Annona cherimola Mill.), litchi (Litchi chinensis Sonn.) and others (Durán et al., 2003, 2006b). However, severe soil erosion occurs frequently on the bare taluses of bench terraces, especially those with sunny southern orientations (Durán et al., 2005). The detached soil from the talus accumulates on the platform of the terrace below, hindering manual fruit harvesting and orchard maintenance. The use of native (mostly weeds) and aromatic and medicinal plants (AMP) to control soil and nutrient losses were also investigated using erosion plots $16 \mathrm{~m}^{2}(4 \times 4 \mathrm{~m})$ in area, and located in the taluses of orchard terraces (Durán et al., 2004b). The severity of soil erosion is thought to vary according to the structure of the bench terrace and the ground cover conditions. Rills are the primary form of erosion on the taluses of orchard terraces with extreme and heavy storms, some of which develop into gullies that can run from the upper terrace down to the 

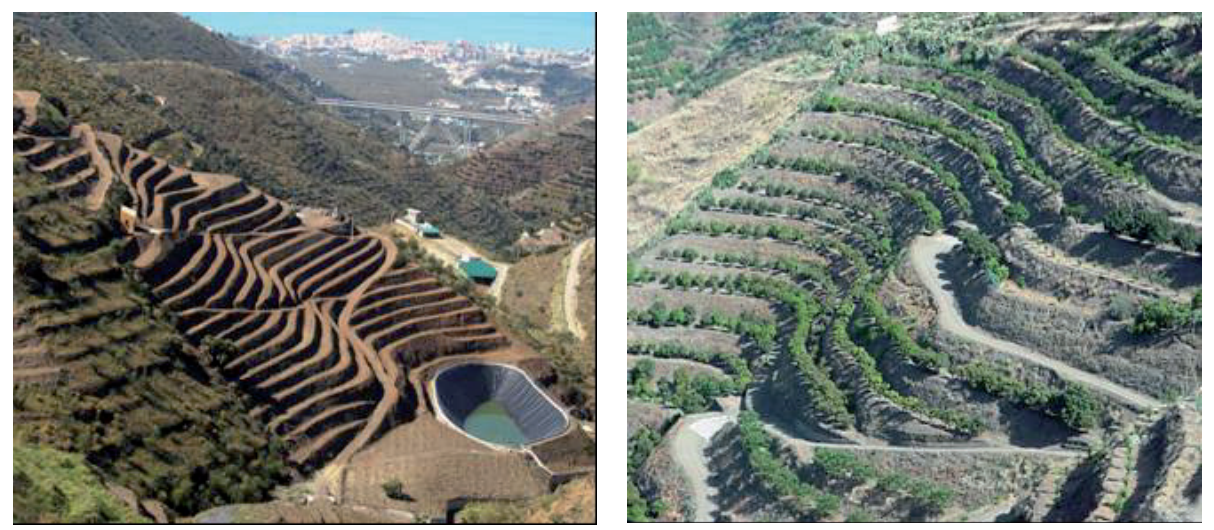

Figure 6. Orchard terraces for subtropical farming species in Granada coast (SE Spain).
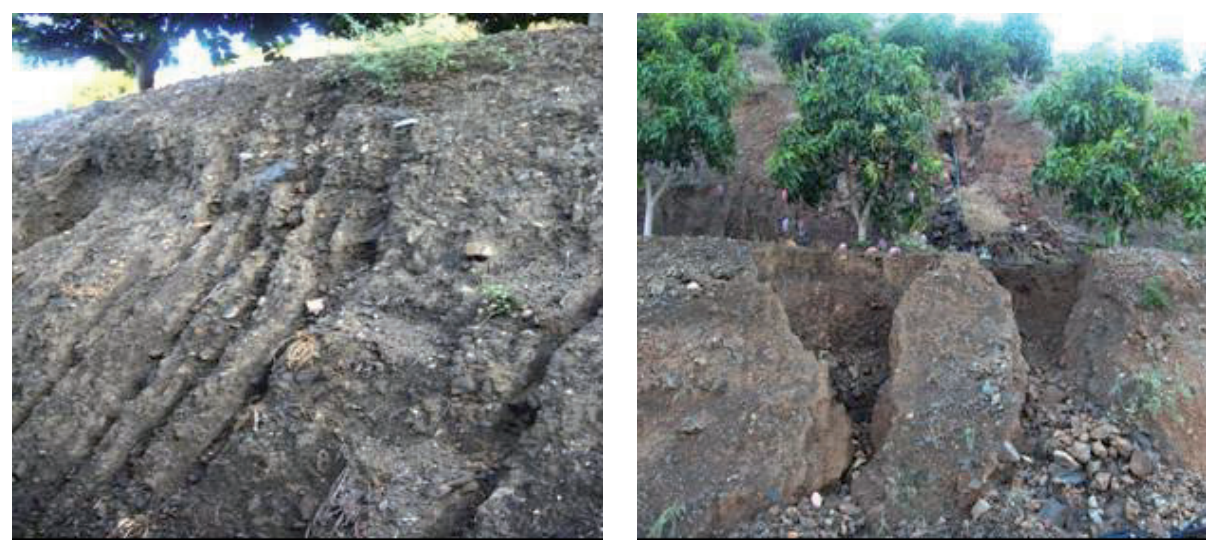

Figure 7. Rills and gullies in the taluses of orchard terraces.
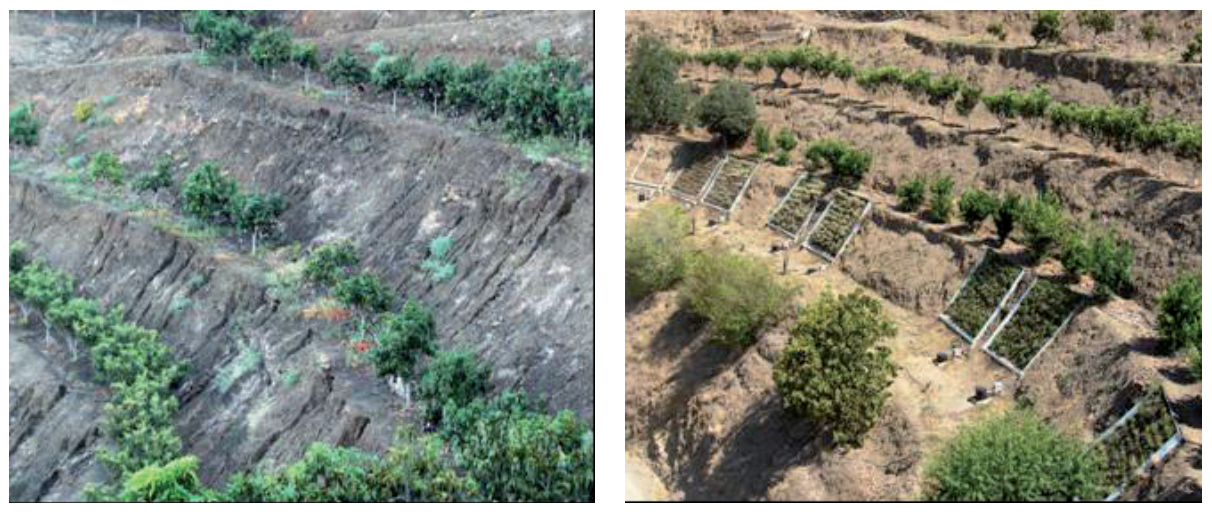

Figure 8. Gullies in the taluses of orchard terraces and plots used for monitoring the erosion control by plant covers.

lower terrace (Fig. 7). Nevertheless, rills and gullies are rarely found on plant-covered taluses. The plant covers of thyme and sage in relation to bare soil reduced erosion by 63 , and $30 \%$, and decreased runoff and by 54 and $40 \%$, respectively (Durán et al., 2002) (Fig. 8). Also, the loss of nutrients (NPK) from taluses of orchard terraces was controlled by plant covers (Durán et al., 2004b). Terrace pollution and erosion (even destruction) were prevented by planting the taluses with covers of plants having aromatic, medicinal, and mellipherous properties. This increased the feasibility of making agricultural use of soils on steep slopes. Moreover, an ecological balance was at least partially restored, reducing pollution that is injurious to the environment as well as to humans.

\section{IMPACT OF PLANT COVERS ON SOIL EROSION}

Runoff is a fundamental process in land degradation, causing soil erosion and influencing the soil water balance and 
Table III. Relationship between vegetation cover and soil loss by sheet and rill erosion.

\begin{tabular}{|c|c|c|c|}
\hline Vegetation type & $\begin{array}{l}\text { Equation erosion } \\
\text { relative }(\mathrm{Er})\end{array}$ & Original equation & Reference \\
\hline \multirow[t]{2}{*}{$\begin{array}{l}\text { Rangelands: grass, } \\
\text { bushes and trees }\end{array}$} & $\mathrm{Er}=\mathrm{e}^{-0.0235 \mathrm{C}}$ & $\begin{array}{l}\mathrm{E}\left(\mathrm{cm} \mathrm{y}^{-1}\right)=0.0668 \mathrm{e}^{-0.0235 \mathrm{C}} \\
\mathrm{R}^{2}=0.89\end{array}$ & Dunne et al. (1978) \\
\hline & $\mathrm{Er}=\mathrm{e}^{-0.0168 \mathrm{C}}$ & $\mathrm{E}=0.9258 \mathrm{e}^{-0.0168 \mathrm{C}}$ & $\begin{array}{l}\text { Rickson and Morgan } \\
\text { (1988) }\end{array}$ \\
\hline Grasses & $\begin{array}{l}\mathrm{Er}=0.0996+ \\
0.9004 \mathrm{e}^{-0.0370 \mathrm{C}}\end{array}$ & $\begin{array}{l}E=433.43+3920.44 e^{-0.037 C} \\
R^{2}=0.56\end{array}$ & $\begin{array}{l}\text { Dadkhah and Gifford } \\
\text { (1980) }\end{array}$ \\
\hline Rangelands: grasses & $\mathrm{Er}=\mathrm{e}^{-0.0300 \mathrm{C}}$ & $\begin{array}{l}\mathrm{E}\left(\mathrm{g} \mathrm{m}^{-2}\right)=10.4856 \mathrm{e}^{-0.0300 \mathrm{C}} \\
\text { rain } 30 \mathrm{~min}, \mathrm{R}^{2}=0.25 \\
\mathrm{E}\left(\mathrm{g} \mathrm{m}^{-2}\right)=34.1240 \mathrm{e}^{-0300 \mathrm{C}} \\
\text { rain during } 60 \mathrm{~min}, \mathrm{R}^{2}=0.37\end{array}$ & $\begin{array}{l}\text { Snelder and Bryan } \\
\text { (1995) }\end{array}$ \\
\hline $\begin{array}{l}\text { Mediterranean } \\
\text { matorral }\end{array}$ & $\begin{array}{l}\mathrm{Er}=\mathrm{e}^{-0.0411 \mathrm{C}} \\
\mathrm{I}=100.7 \mathrm{~mm} \mathrm{~h}^{-1}\end{array}$ & $\begin{array}{l}\mathrm{E}\left(\mathrm{g} \mathrm{L}^{-1}\right)=5.4172 \mathrm{e}^{-0.0411 \mathrm{C}} \\
\mathrm{R}^{2}=0.99\end{array}$ & $\begin{array}{l}\text { Francis and Thornes } \\
\text { (1990) }\end{array}$ \\
\hline Pasture & $\mathrm{Er}=\mathrm{e}^{-0.0435 \mathrm{C}}$ & $\mathrm{E}=0.6667 \mathrm{e}^{-0.0435 \mathrm{C}}$ & $\begin{array}{l}\text { Elwell and Stoking } \\
\text { (1976) }\end{array}$ \\
\hline \multirow[t]{2}{*}{ Rangeland: grasses } & $\mathrm{Er}=\mathrm{e}^{-0.0455 \mathrm{C}}$ & $\begin{array}{l}\mathrm{E}\left(\mathrm{g} \mathrm{m}^{-2}\right)=653.27 \mathrm{e}^{-0.0455 \mathrm{C}} \\
\mathrm{R}^{2}=0.62\end{array}$ & Moore et al. (1979) \\
\hline & $\mathrm{Er}=\mathrm{e}^{-0.0477 \mathrm{C}}$ & $\begin{array}{l}E\left(\mathrm{tha}^{-1}\right)=64.4240 \mathrm{e}^{-0.0477 \mathrm{C}} \\
\mathrm{R}^{2}=0.99\end{array}$ & Lang (1990) \\
\hline Pasture & $\mathrm{Er}=\mathrm{e}^{-0.0527 \mathrm{C}}$ & $\mathrm{E}=0.9559 \mathrm{e}^{-0.0527 \mathrm{C}}$ & $\begin{array}{l}\text { Elwell (1980); Elwell } \\
\text { and Stocking (1974) }\end{array}$ \\
\hline Pasture: grasses & $\mathrm{Er}=\mathrm{e}^{-0.0593 \mathrm{C}}$ & $\begin{array}{l}E\left(t h a^{-1}\right)=16.857 e^{-0.0593 C} \\
R^{2}=0.96\end{array}$ & Lang (1990) \\
\hline Pasture: grasses & $\mathrm{Er}=\mathrm{e}^{-0.0694 \mathrm{C}}$ & $\begin{array}{l}\mathrm{E}\left(\mathrm{t} \mathrm{ha}^{-1}\right)=335.38 \mathrm{e}^{-0.0694 \mathrm{C}} \\
\mathrm{R}^{2}=0.98\end{array}$ & Lang (1990) \\
\hline $\begin{array}{l}\text { Cultivated land: sugar } \\
\text { beet }+ \text { mulch }\end{array}$ & $\begin{array}{l}\mathrm{Er}=\mathrm{e}^{-0.0790 \mathrm{C}} \\
\mathrm{R}^{2}=0.86\end{array}$ & $\mathrm{E}=136 \mathrm{e}^{-0.0790 \mathrm{C}}$ & Kainz (1989) \\
\hline $\begin{array}{l}\text { Mediterranean } \\
\text { matorral }\end{array}$ & $\begin{array}{l}\mathrm{Er}=\mathrm{e}^{-0.0816 \mathrm{C}} \\
\mathrm{I}=25.8 \mathrm{~mm} \mathrm{~h}^{-1}\end{array}$ & $\begin{array}{l}E(g \text { L-1 })=5.5669 \mathrm{e}^{-0.0816 C} \\
\mathrm{R}^{2}=0.99\end{array}$ & $\begin{array}{l}\text { Francis and Thornes } \\
\text { (1990) }\end{array}$ \\
\hline
\end{tabular}

The equations reflect the combined effect of both above-ground (stems and leaves) and below-ground (roots) biomass. C, vegetation cover (\%); Er, erosion, relative to erosion of a bare soil; E, erosion; I, rainfall intensity.

hydrology of the catchments. Many authors have discussed the runoff behaviour of different land-use types and the effects of land-use change on runoff production (Kosmas et al., 1997; Narain et al., 1998; Cammeraat and Imeson, 1999; Bellot et al., 2001; McDonald et al., 2002; Pardini et al., 2003). In the context of afforestation/reforestation or vegetation restoration, it is commonly concluded that runoff rates and peak flows are reduced (Mapa, 1995; Zhou et al., 2002; Zhang et al., 2004, Marqués et al., 2005), but also base flows may decrease as a result of increased evapotranspiration (Bruijnzeel, 2004). Pilgrim et al. (1988) stress the importance of an increased knowledge concerning the impact of vegetation, land management and grazing practices on runoff production to support decision making in land-use planning in arid and semiarid regions. A significant number of studies have been conducted on runoff processes in relation to vegetation and other variables in semi-arid regions, but the majority of them focus on the Mediterranean environment (Sala and Calvo, 1990; Sorriso et al., 1995; Nicolau et al., 1996; Castillo et al., 1997; Puigdefábregas et al., 1999; Lasanta et al., 2000; Archer et al., 2002; Calvo et al., 2003). More studies refer to runoff characteristics in arable land than to natural vegetation and rangeland areas (Mapa, 1995; Descroix et al., 2001; Archer et al., 2002).
Studies on runoff processes in rangelands have been conducted mainly in North America (Wilcox and Wood, 1988, 1989). Gutierrez and Hernandez (1996) further indicate the great uncertainty regarding the amount of vegetation cover needed to counteract runoff in semi-arid rangelands.

From these studies it is clear that for a successful soil and water conservation strategy is urgent in order to combat runoff by vegetation restoration. The resulting higher infiltration benefits plant growth and biomass production and can also lead to groundwater recharge, thus replenishing deeper-lying water resources. Another important advantage of the decreased in runoff is that lower-lying croplands become less subject to damaging floods from the formerly degraded steep hillslopes.

Many authors have demonstrated that in a wide range of environments both runoff and sediment loss will decrease exponentially as the percentage of vegetation cover increases (Tab. III). Semi-arid landscapes by definition are water-limited and therefore are potentially sensitive to environmental change (Schlesinger et al., 1990) and its effect on biomass production. However, hilly areas in the Mediterranean with sclerophyllous vegetation are not necessarily of low biomass production, especially those with annual rainfall of $400 \mathrm{~mm}$ or more, in 
which biomass production ranges from $170 \mathrm{tha}^{-1}$ to $350 \mathrm{tha}^{-1}$ (Bazivilinch et al., 1971; Whittaker and Likens, 1973).

\subsection{Mediterranean characteristics affecting vegetation}

The Mediterranean climate has, in effect, three different definitions: (1) climate of the Mediterranean Sea and bordering land areas; (2) climate that favours broad-leaved, evergreen, sclerophyllous shrubs and trees; (3) winter-wet, summer-dry climate. However, portions of the Mediterranean region do not have winter-wet, summer-dry climate, while parts that do may not have evergreen sclerophylls. Places situated away from the Mediterranean Sea have more Mediterranean climate than anywhere around the sea under the third definition. Broad-leaved evergreen sclerophylls dominate some regions with non-Mediterranean climates, typically with summer precipitation maximum as well as winter rain, and short droughts in spring and fall. Thus, such plants may be said to characterize subtropical semi-arid regions. On the other hand, where summer drought is most severe, i.e. the most Mediterranean climate under definition 3, broad-leaved evergreen sclerophylls are rare to absent. Rather than correlating with sclerophyll dominance, regions of extreme winter-wet, summer-dry climate characteristically support a predominance of annuals, the life form best adapted to seasonal rainfall regimes. Therefore, the characteristics of the climate of an area that can affect vegetation growth and vegetation cover and therefore soil erosion are rainfall, both amount and intensity, and aridity.

Erosion data collected in various sites along the Mediterranean region show that the amount of rainfall has a crucial effect on soil erosion. Generally, there is a tendency towards increasing runoff and sediment loss with decreasing rainfall in hilly Mediterranean shrublands, especially in the region where rainfall is greater than $300 \mathrm{~mm} \mathrm{yr}^{-1}$. Below the $300 \mathrm{~mm}$ annual rainfall limit, runoff and sediment loss diminish with decreasing rainfall. Rainfall amount and distribution are the major determinants of biomass production on hilly lands. Lower amounts of rainfall combined with high rates of evapotranspiration drastically reduce the soil moisture content available for plant growth. In areas with annual precipitation of less than $300 \mathrm{~mm}$ and high evapotranspiration rates, the soil water available to the plants is severely reduced.

Aridity is a critical environmental factor in determining the evolution of natural vegetation by considering the water stress, which may occur and cause reduced plant cover. In the Mediterranean region, vegetation presents a great capacity of adaptation and resistance to dry conditions, and numerous species can survive many months through prolonged droughts with soil-moisture content below the theoretical wilting point. Aridity can greatly affect plant growth and vegetation cover, particularly annual plants. Under dry climatic conditions in areas cultivated with rainfed cereals, the soil remains bare, favouring high erosion rates under heavy rainfalls following a long dry period. Closely related to climatic characteristics is the topographic attribute, slope orientation, which is considered an important factor for land-degradation processes. In the Mediterranean region, slopes with southern and western facing orientations are warmer, and have higher evaporation rates and lower water-storage capacity than northern and eastern orientations. Therefore, a slower recovery of vegetation and higher erosion rates are expected in southern and western than in northern and eastern orientations. As a consequence, southern exposed slopes usually have a persistently lower vegetation cover than northern exposed slopes. The degree of erosion measured along south-facing hill slopes is usually much higher (even two-fold) than in the north-facing slopes under various types of vegetation cover.

Indicators of soil erosion related to the existing vegetation can be considered in relation to: (a) fire risk and ability to recover, (b) erosion protection offered to the soil, and (c) percentage of plant cover. Forest fires are one of the most important causes of land degradation in hilly areas of the Mediterranean region. During recent decades, fires have become very frequent especially in the pine-dominated forests, with dramatic consequences in soil erosion rates and biodiversity losses. Also, Mediterranean pastures are frequently subjected to human-induced fires in order to renew the biomass production. The Mediterranean vegetation type is highly inflammable and combustible due to the existence of species with a high content of resins or essential oils. Conversely, it is known that vegetation has a high ability to recover after fire, and the environmental problems related to fire normally last for only a limited number of years after the fire.

Human interference, such as livestock grazing or change in the land-use pattern, may irreversibly damage the recovering vegetation. Particularly, in hilly areas the indiscriminate uprooting of aromatic and medicinal plants could promote the soil erosion (Durán et al., 2004a, 2006a).

Vegetation and land use are clearly important factors controlling the intensity and the frequency of overland flow and surface wash erosion. Among the prevailing perennial agricultural crops in the Mediterranean, olive trees present a particularly high adaptation and resistance to long-term droughts and support a remarkable diversity of flora and fauna in the undergrowth. This undergrowth is even higher than for some natural ecosystems.

Under these conditions, annual vegetation and plant remains form a satisfactory soil-surface cover can prevent surface sealing, minimising the velocity of the overland water. In the case where the land is intensively cultivated, higher erosion rates are expected. Many studies have shown that the variation in runoff and sediment yields in drainage basins can be attributed to changes in the vegetation cover and land-use management. A value of $40 \%$ vegetative cover is considered critical, below which accelerated erosion dominates in a sloping landscape. This threshold may be shifted for different types of vegetation, rain intensity, and land attributes. It shows, however, that degradation begins only when a substantial portion of the land's surface is denuded; then it proceeds at an accelerated rate that cannot be arrested by land resistance alone. Deep soils on unconsolidated parent materials show slow rates of degradation and loss of their biomass production potential. By contrast, shallow soils with lithic contact on steep slopes 
have low productivity, and low erosion tolerance if they are not protected by vegetation.

\subsection{Plant roots and erosion control}

Many soil-erosion studies focus on the effects of plant cover, whereas much less attention has been paid to the effects of plant roots on water erosion processes (Gyssels et al., 2005; de Baets et al., 2006, 2007a; Reubens et al., 2007). The impact of roots on water erosion rates might become critical when the above ground biomass disappears because of grazing or surface fire and when concentrated flow occurs. Especially in semi-arid environments, where plant covers can be restricted and shoots can temporally disappear, roots can play a crucial role. Bui and Box (1993) showed that roots had no stabilizing effect during interrill soil erosion, but Ghidey and Alberts (1997) found that interrill erodibility decreased as dead root mass and dead root length increased. The decline in soil loss is even more pronounced in the case of rill and ephemeral gully erosion. Studies on the effects of roots on concentrated flow erosion rates (Li et al., 1991; Zhou and Shangguan, 2005; Gyssels et al., 2006; de Baets et al., 2006) used several root parameters to describe the root effect (root density, root lengthdensity, root dry weight, root surface area density and root area ratio). Most studies use root density or root-length density to predict the effects of roots on soil erosion rates by concentrated flow. Few studies report an effect of root diameter on the erosion resistance of the topsoil to concentrated flow erosion. Many authors reported an exponential decline of rill erodibility and soil detachment rates with increasing root-length densities or root densities (Mamo and Bubenzer, 2001a, b; Gyssels et al., 2006; de Baets et al., 2006). Li et al. (1991) reported that soil-erosion resistance increased exponentially with greater root density and that the ability of plant roots to bolster soilerosion resistance depends mainly on the distribution of roots and on the number of fibrous roots less than $1 \mathrm{~mm}$ in diameter. Zhou and Shangguan (2005) observed a similar relation but with root surface-area density as the root variable. According to Gyssels et al. (2005) fine roots ( $<3 \mathrm{~mm}$ in diameter) are considered more important to soil fixation than coarse roots. Decades ago, Wischmeier (1975) and Dissmeyer and Foster (1985) pointed out that species with contrasting root architectures have a different erosion-reducing effect, and recently de Baets et al. (2007b) and Reubens et al. (2007). In general, the distinction between the root systems, consists mainly in whether the first root keeps on growing and performs as a thick primary root with few or many laterals (gymnosperms and dicotyledons) or disappears (monocotyledons). In the monocotyledons, the first root commonly lives a short time and the root system is formed by adventitious roots sprouting from that shoot, often in connection with buds.

The decrease in water-erosion rates with increasing vegetation cover is exponential, as pointed out above. According to Gyssels et al. (2005), the decline water erosion rates with expanding root mass is also exponential, as reflected in the following equation:

$$
\mathrm{SEP}=\mathrm{e}^{-\mathrm{bRP}}
$$

where SEP is the soil-erosion parameters (interrill or rill erosion rates of bare top soils without roots), RP is a root parameter (root density or root-length density) and $\mathrm{b}$ is a constant that indicates the effectiveness of the plant roots in reducing soil-erosion rates.

For splash erosion, $\mathrm{b}$ is zero, for interrill erosion the $\mathrm{b}$-value is 0.1195 when root density $\left(\mathrm{kg} \mathrm{m}^{-3}\right)$ is used as root parameter, and 0.0022 when root-length density $\left(\mathrm{km} \mathrm{m}^{-3}\right)$ is used. For rill erosion these average b-values are 0.5930 and 0.0460 , respectively. The similarity of this equation for root effects with the equation for vegetation cover effects is striking (Tab. IV). Moreover, all the studies on the impact of the vegetation cover attribute soil-loss reduction to the above-ground biomass only, whereas in reality this reduction results from the combined effects of roots and canopy cover. (Gyssels and Poesen, 2003).

It is well-know (as mentioned above) that plants reduce soil erosion by intercepting raindrops, enhancing infiltration, transpiring soil water and by providing additional surface roughness by adding organic substances to the soil (Styczen and Morgan, 1995). Plant roots have a mechanical effect on soil strength. By penetrating the soil mass, roots reinforce the soil and increase the soil shear strength (Styczen and Morgan, 1995). Since roots bind soil particles at the soil surface and increase surface roughness, they reduce the susceptibility of the soil to rill and gully erosion. Roots also have hydrological effects by increasing surface roughness and soil permeability, roots increase soil infiltration capacity. While the aboveground shoots bend over and cover the surface or reduce flow velocity when concentrated flow occurs, roots physically restrain or hold soil particles in place (Gray and Sotir, 1996). Prosser et al. (1995) showed that the critical flow-shear stress decreased by clipping off the above ground vegetation, but that the dense root network prevented the surface from significant scour and sediment transport.

Most of the existing root studies deal with agricultural crops i.e. the effect of maize (Zea mays L.) roots on interrill erosion rates was studied by Bui and Box (1993). Mamo and Bubenzer (2001a), studied the effect of soybean (Glycine max L.) and maize (Zea mays L.) roots on rill erodibility and found significant differences in channel erodibility and soil detachment rates between root-permeated and fallow soils.

A few studies report the effects of roots of natural vegetation on erosion processes. Li et al. (1991) examined the effect of roots of Pinus tabulaeformis and Hippophae rhamnoides on rill erodibility. Sidorchuk and Grigorev (1998) reported the effect of the root density of tundra vegetation on the critical shear velocity for different soil types. Meanwhile, de Baets et al. (2007a) described the root characteristics of Mediterranean plant species and their erosion-reducing potential during concentrated runoff, showing the implications for ecological restoration and management of erosionprone slopes. Tengbeh (1993) investigated the effects of grassroot density on the shear strength increase with decreasing soil moisture content. In this context, both soil type and soil-moisture conditions control root architecture (Schenk and Jackson, 2002) and soil-erosion rates (Govers et al., 1990). It is important to understand the effects of soil type and soil moisture on the erosion-reducing potential of plant roots. Sheridan 


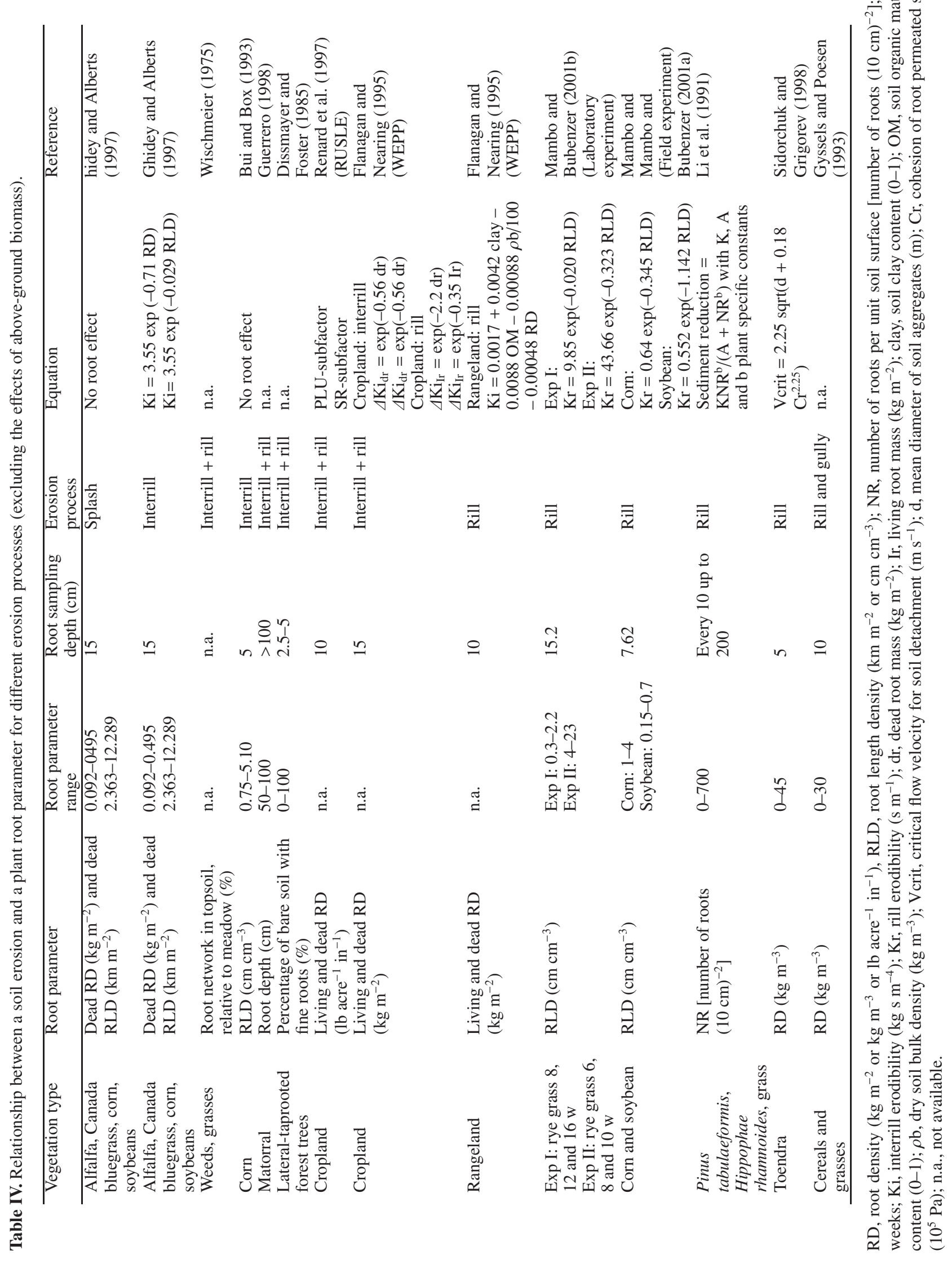


et al. (2000) found low rill erodibilities for clay and silt soils, and high erodibilities for soils with particle sizes larger than silt but $<10 \mathrm{~mm}$, reflecting different levels of cohesion. The resistance of the soil to concentrated flow erosion increases with growing initial soil-moisture content (Govers et al., 1990).

Li et al. (1991) and Mamo and Bubenzer (2001b) reported the effects of grass roots (ryegrass) on concentrated flow erosion. So far, it is not clear to what extent grass roots contribute to the erodibility of topsoil during concentrated flow, because different relationships were reported. Moreover, grasses grow in many different environments which can be threatened by concentrated overland flow, for instance after surface fire or overgrazing. Once the above ground biomass has disappeared, only roots can offer resistance to concentrated flow erosion. Kort et al. (1998) indicated that post-burning erosion on a naturally vegetated rangeland dominated by grass species did not differ for simulated rainfall intensities. This indicates that the network of fibrous roots in the soil surface layers contributes to erosion control. These authors state that grasses provide perennial protection and minimal soil erosion. Moreover, grasses have proven to be the most effective for erosion control in most areas, because they germinate quickly, providing a complete ground cover (Brindle, 2003) and a dense root network that reinforces the soil by adding extra cohesion (Gray and Leiser, 1982). Additionally, Li et al. (1991) reported that the effect of roots in increasing soil resistance is highly dependent on the presence of effective roots (fibrils $<1 \mathrm{~mm}$ ). Also Gyssels and Poesen (2003) indicate that cross-sectional areas of gullies under grassy field parcels were much smaller than under agricultural cropland for the same flow intensity.

\subsubsection{The effect of roots on soil properties}

The shear strength of a soil has been recognized as a determinant of its resistance to erosion. From the start of slopestability research it was clear that plant roots were vital for soil reinforcement. The shear strength of a soil is a measure of its cohesiveness and resistance to shearing forces exerted by gravity, moving fluids and mechanical loads. Soil is strong in compression, but weak in tension. Plant roots are weak in compression, but strong in tension. When combined, the soil-root matrix produces a type of reinforced earth which is much stronger than the soil or the roots separately (Simon and Collison, 2001). Thus, roots reinforce the soil (Anderson and Richards, 1987). This conclusion was found independently by different researchers (Gray and Leiser, 1982), showing that soil erodibility is inversely proportional to the resistance of the soil to erosion. In this context, the intrinsic properties of the soil such as aggregate stability, infiltration capacity, soil bulk density, soil texture, organic and chemical content and shear strength are the most important determinants.

According to Amezketa (1999) the positive impact of plant roots and root hairs on soil aggregation and stability consist of many effects, such as:

1. enmeshing fine particles into stable macro-aggregates by root secretions, even when the root is dead;
2. drying the soil environment around the roots, reorienting clay particles parallel to the axis of the roots and drawing soil particles together;

3. supplying decomposable organic residues to the soil;

4. supporting a large microbial population in the rhizosphere;

5. providing food for soil animals;

6. releasing polyvalent cations and increasing concentrations of ions in solution.

Field observations in southeast Asia reported by Ryan (1995) and Turkelboom et al. (1997) show that soil loss in newly prepared fields is generally very slight in the first year after clearing, as the roots of the fallow vegetation create stable aggregates, but losses augment rapidly afterwards as the roots decay and aggregates break down. The effect of living roots on soil-structure stability depends on the plant species. Monocotyledonous plants are superior to dicotyledonous plants and grasses are better than cereals in stabilizing aggregates, because the former contain a much larger root biomass with exudates (Glinski and Lipiec, 1990; Amezketa, 1999). Maize and tomato, on the other hand, can decrease soil aggregate stability by chelating iron and aluminium, thus destroying chemical bonds with organic matter (Reid and Goss, 1987).

Plant roots penetrating the soil leave macropores that improve water movement and gaseous diffusion. They contribute to the system of continuous pores in the soil and enhance the infiltration capacity of the soil (Glinski and Lipiec, 1990). Li et al. (1992) indicates that soil infiltration increases because plant roots improve the noncapillary porosity of the soil and promote the formation of water-stable aggregates of $2-5 \mathrm{~mm}$, and $>5 \mathrm{~mm}$ in diameter. A higher soil infiltration capacity reduces the runoff volume and consequently soil erosion.

Roots growing in the soil occupy space that was previously occupied by soil pore space and soil particles. Since root diameter is usually larger than soil pores, soil particles are pushed aside and the bulk density of the soil up to $8 \mathrm{~mm}$ near the root increases (Glinski and Lipiec, 1990). However, fine roots less than $1 \mathrm{~mm}$ in diameter can significantly decrease the bulk density of the soil and increase the soil porosity (Li et al., 1992, 1993). This effect depends on the root diameter and the nature of the soil, and erosion resistance presumably derives from the large number of roots in the topsoil.

Texture, organic content, and chemical composition of a soil are important because of their influence on soil-aggregate stability (Morgan, 1996). According to Sakkar et al. (1979), modifications in particle-size distribution and composition of the clay fraction was found within the rhizosphere around French bean roots. These researchers attributed the changes in texture and mineralogy to an intensified weathering of the soil materials around the plant root. Preferential uptake of ions or water by roots leads to depletion or accumulation profiles of ions. Examples of this are depletion zones of phosphorus and potassium or the accumulation of sodium and chlorine (Glinski and Lipiec, 1990; Pojasok and Kay, 1990). Finally, roots also have a positive effect on soil aggregation by supplying decomposable organic residues to the soil, supporting a large microbial population in the rhizosphere and providing 
food for soil animals (Tisdall and Oades, 1982; Amezketa, 1999).

\subsection{Plant cover and biodiversity}

The biological diversity existing in any natural ecosystem is directly related to the amount of living and nonliving organic matter present in the ecosystem (Wright, 1990). By diminishing soil organic matter and overall soil quality, erosion reduces biomass productivity in ecosystems. Plants, animals, and microbes are vital components of the soil, as mentioned above, and constitute a large measure of the soil biomass. One square meter of soil may support about 200,000 arthropods and enchytraeids and billions of microbes (Wood, 1989; Lee and Foster, 1991). A hectare of productive soil may have a microbial and invertebrate biomass weighing nearly $10000 \mathrm{~kg} \mathrm{ha}^{-1}$. In this context, Anderson (1978) reported that a forest soil with abundant organic matter supports up to 1000 species of animals per square meter, including arthropods, nematodes, and protozoa.

Erosion rates that are 10-20 times higher than the sustainability rate (less than 0.5 to $1 \mathrm{Mg} \mathrm{ha}^{-1} \mathrm{yr}^{-1}$ ) decrease the diversity and abundance of soil organisms (Atlavinyte, 1964), whereas agricultural practices that maintain adequate soil organic-matter content favour the proliferation of soil biota (Reid, 1985).

Macrofauna (mostly arthropods) species diversity more than doubled when organic manure was added to grassland plots in Japan (Kitazawa and Kitazawa, 1980). Rodríguez et al. (2007b) in south-eastern Spain pointed out the proliferation of arthropod species under plant covers in comparison to uncovered bare soils in the taluses of orchard terraces.

Because increased biomass is generally correlated with increased biodiversity, greater biomass of arthropods and microbes implies an increase in biodiversity (Pimentel et al., 1992).

The effects of erosion may be responsible for the loss of a keystone species, an absence that may have a cascading effect on a wide array of species within the agroecosystem. Species that act as keystone species include plant types that maintain the productivity and integrity of the ecosystem; predators and parasites that control the feeding pressure of some organisms on vital plants; pollinators of various vital plants in the ecosystem; seed dispersers; and the plants and animals that provide a habitat required by other essential species, such as biological nitrogen fixers (Heywood, 1995).

Soil biota performs many beneficial activities that improve soil quality and productivity. For example, soil biota recycles basic nutrients required by plants for growth (Pimentel et al., 1980). In addition, the tunnelling and burrowing of earthworms and other organisms enhance productivity by increasing water infiltration into the soil.

This churning and mixing of the upper soil redistributes nutrients, aerates the soil, exposes matter to the climate for soil formation, and increases infiltration rates, thus enhancing conditions for soil formation and plant productivity. Controlling erosion not only conserves the quality of soils but enhances vegetative growth and increases total biodiversity.

\section{CONCLUSION}

Soil erosion is a natural process which has been greatly accelerated by human action. A reduction in plant cover can intensify erosion processes that diminish soil quality. In arid and semi-arid areas with sparse vegetation cover, it is urgent protect the soil by understanding degradation processes and establishing adequate management measures. Moreover, the proven efficiency of the plant covers for the restoration of degraded environments should be considered more widely. Research needs to concentrate future efforts on developing ecological successions and revegetation methods which promote a substantial and sustainable canopy cover.

Some of the basic reflections of this review include:

1. Plant covers maintain crucial interrelationship with soil properties, enhancing biodiversity for steeply sloped areas that have highly erodible soils. Erosion is likely to be more affected by changes in rainfall and plant cover than runoff, though both are influenced.

2. Changes in plant cover have a greater impact on both runoff and erosion than changes in canopy cover alone. Insights into soil-erosion processes and the renewed hydrological situation encouraged by plant covers can provide a valuable design for new strategies of erosion management and ecosystems restoration.

3. The inappropriate removal of plant cover and the intense farming systems of mountain areas endanger land conservation, raising an urgent need to implement appropriate land management which has a large-scale perspective but acts at the local level.

4. Erosion can be mitigated through a process of assessment at regional scales to set broad targets, for development and restoration of the plant cover, and the introduction of conservation measures within the areas at greatest risk.

Therefore, at both regional and local scales, the plant cover deserves careful assessment for the sustainable management of soil resources, in order to avoid catastrophic degradation. This will help adapt to land-use change and, in terms of conservation, it will aid in establishing an equilibrium between economic and environmental interests.

Acknowledgements: Partly of research work that leads to this publication was sponsored by following research project "Environmental Impact of Farming Subtropical Species on Steeply Sloping Lands. Integrated Measures for the Sustainable Agriculture" (RTA05-00008-00-00), granted by INIA, Spain.

\section{REFERENCES}

Abu-Zreig M., Rudra R.P., Lalonde M.N., Whiteley H.R., Kaushik N.K. (2004) Experimental investigation of runoff reduction and sediment removal by vegetated filter strips, Hydrol. Process. 18, 2029-2037.

Abu Hammad H.A., Borresen T., Haugen L.E. (2006) Effect of rain characteristics and terracing on runoff and erosion under the Mediterranean, Soil Till. Res. 87, 39-47. 
Albadalejo J., Stocking M.A. (1989) Comparative evaluation of two models in predicting storm soil loss from erosion plots in semiarid Spain, Catena 16, 227-236.

Amezketa E. (1999) Soil aggregate stability: a review, J. Sustain. Agr. 14, 83-151.

Anderson J.M. (1978) Inter- and intra-habitat relationships between woodland cryptostigmata species diversity and the diversity of soil and litter microhabitats, Oecologia 32, 341-348.

Anderson M.G., Richards K.S. (1987) Slope stability; geotechnical engineering and geomorphology, Wiley and Sons, Chichester, UK.

Archer N., Hess T., Quinton J. (2002) The water balance of two semi-arid shrubs on abandoned land in South-Eastern Spain after cold season rainfall, Hydrol. Earth Syst. Sc. 6, 913-926.

Assouline S. (2004) Rainfall-induced soil surface sealing: a critical review of observations, conceptual models, and solutions, Vadose Zone J. 3, 570-591.

Atlavinyte O. (1964) Distribution of earthworms (Lumbricidae) and larval insects in the eroded soil under cultivated crops, Pedobiologia $4,245-250$.

Bajracharya R.M., Lal R., Kimble J.M. (1998) Soil organic carbon dynamics under simulated rainfall as related to erosion and management in central Ohio, in: Blume H.P. (Ed.), Towards a sustainableland use, Advances in Geoecology 31, Vol. 1, Catena-Verlag, Germany, pp. 231-238.

Barrows H.L., Kilmer V.J. (1963) Plant nutrient losses from soils by water erosion, Adv. Agron. 15, 303-315.

Bazivilinch N.I., Robin L.Y., Rozon N.N. (1971) Geomorphological aspects of productivity, Sov. Geogr. 12, 293-317.

Bellot J., Escarré A. (1998) Stemflow and throughfall determination in a resprouted Mediterranean holm-oak forest, and changes by precipitation trends, Ann. Sci. For. 55, 847-865.

Bellot J., Bonet A., Sanchez J.R., Chirino E. (2001) Likely effects of land use changes on the runoff and aquifer recharge in a semiarid landscape using a hydrological model, Landscape Urban. Plan. 55, $41-$ 53.

Blondel J., Aronson J. (1999) Biology and wildlife of the Mediterranean region, Oxford University Press, Oxford UK.

Bochet E., Rubio J.L., Poesen J. (1998) Relative efficiency of three representative matorral species in reducing water erosion at the microscale in a semi-arid climate, Geomorphology 23, 139-150.

Bochet E., Poesen J., Rubio J. (2000) Mound development as an interaction of individual plants with soil, water erosion and sedimentation processes on slopes, Earth Surf. Proce. Land. 25, 847-867.

Bochet E., Poesen J., Rubio J.L. (2006) Runoff and soil loss under individual plants of a semi-arid Mediterranean shrubland: influence of plant morphology and rainfall intensity, Earth Surf. Proc. Land. 31, 536-549.

Brandt J., Thornes J. (1987) Erosional energetics, in: Gregory K.L. (Ed.), Energetics of Physical Environment, pp. 51-87.

Branson F.A., Owen J.B. (1970) Plant cover, runoff, and sediment yield relationships on Mancos shale in Western Colorado, Water Resour. Res. 6, 184-790.

Bradford J.M., Ferris J.E., Remley P.A. (1987) Interrill soil erosion processes: I. Effect of surface sealing on infiltration, runoff, and soil splash detachment, Soil Sci. Soc. Am. J. 51, 1566-1571.

Brindle F.A. (2003) Use of native vegetation and biostimulants for controlling soil erosion on steep terrain, Journal of the Transportation Research Board, Eighth International Conference on Low Volume Roads, vol. 1, pp. 203-209.

Bruijnzeel L.A. (2004) Hydrological functions of tropical forests: not seeing the soil for the trees? Agr. Ecosyst. Environ. 104, 185-228.

Bui E.N., Box J.E. (1993) Growing corn root effects on interrill soil erosion, Soil Sci. Soc. Am. J. 57, 1066-1070.
Calvo C.A., Boix-Fayos C., Imeson A.C. (2003) Runoff generation, sediment movements and soil water behaviour on calcareous (limestone) slopes of some Mediterranean environments in southeast Spain, Geomorphology 50, 269-291.

Cammeraat L.H., Imeson A.C. (1999) The evolution and significance of soil-vegetation patterns following land abandonment and fire in Spain, Catena 37, 107-127.

Castillo V.M., Martínez-Mena M., Albaladejo J. (1997) Runoff and soil loss response to vegetation removal in a semiarid environment, Soil Sci. Soc. Am. J. 61, 1116-1121.

Chaney K., Swift R.S. (1984) The influence of organic matter on aggregate stability in some British soils, J. Soil Sci. 35, 223-230.

Chirino E., Bonet A., Bellot J., Sánchez J.R. (2006) Effects of 30-year-old Aleppo pine plantations on runoff, soil erosion, and plant diversity in a semi-arid landscape in south eastern Spain, Catena 65, 19-29.

Collins H.P., Elliott E.T., Paustian K., Bundy L.C., Dick W.A., Huggins D.R. (2000) Soil carbon pools and fluxes in long-term corn belt agroecosystems, Soil Biol. Biochem. 32, 157-168.

Dadkhah M., Gifford G.F. (1980) Influence of vegetation, rock cover and trampling on infiltration rates and sediment production, Water Res. Bull. 16, 979-986.

de Baets S., Poesen J., Gyssels G., Knapen A. (2006) Effects of grass roots on the erodibility of topsoils during concentrated flow, Geomorphology 76, 54-67.

de Baets S., Poesen J., Knapen A., Barbera G.G., Navarro J.A. (2007a) Root characteristics of representative Mediterranean plant species and their erosion-reducing potential during concentrated runoff, Plant Soil 294, 169-183.

de Baets S., Poesen J., Knapen A., Galindo P. (2007b) Impact of root architecture on the erosion-reducing potential of roots during concentrated flow, Earth Surf. Proc. Land. 32, 1323-1345.

de Luis M. (2000) Estudio espacial y temporal de las tendencias de lluvia en la Comunidad Valenciana (1961-1990), Geoforma, Logroño.

de Ploey J., Savat J., Moeyersons J. (1976) Differential impact of some soil loss factors on flow, runoff creep and rainwash, Earth Surf. Proc. 1, 151-161.

Descroix L., Viramontes D., Vauclin M., Gonzalez Barrios J.L., Esteves M. (2001) Influence of soil surface features and vegetation on runoff and erosion in the Western Sierra Madre (Durango, Northwest Mexico), Catena 43.

di Castri F. (1981) Mediterranean-type shrublands of the world, in: di Castri F., Goodall D.W., Specht R.L. (Eds.), Ecosystems of the world 11: Mediterranean-type shrublands, Elsevier, Amsterdam, The Netherlands, pp. 1-52.115-135.

Díaz E., Roldán A., Lax A., Albaladejo J. (1994) Formation of stable aggregates in degraded soils byamendment with urban refuse and peat, Geoderma 63, 277-288.

Diekkruger B., Bork H.R. (1994) Temporal variability of soil surface crust conductivity, Soil Tech. 7, 1-18.

Dissmeyer G.E., Foster G.R. (1985) Modifying the universal soil loss equation for forest land, in: El-Swaify S.A., Moldenhauer W.C., Lo A. (Eds.), Soil and Erosion Conservation, Soil Conservation Society of America: Ankeny, USA, pp. 480-495.

Dixon R.K., Brown S., Houghton R.A., Solomon A.M., Trexler M.C., Wisniewski J. (1994) Carbon pools and flux of forest global ecosystems, Science 263, 185-190.

Dunne T., Dietrich W.E., Brunengo M.J. (1978) Recent and past erosion rates in semi-arid Kenya, Z. Geomorphol. Supplement Band 29, 130-140.

Durán Z.V.H., Martínez R.A., Aguilar R.J. (2002) Control de la erosión en los taludes de bancales en terrenos con fuertes pendientes, Edafología 9, 1-10.

Durán Z.V.H., Martínez R.A., Aguilar R.J. Franco T.D. (2003) El cultivo del mango (Mangifera indica L.) en la costa granadina, Granada, Spain. 
Durán Z.V.H., Francia M.J.R., Martínez R.A. (2004a) Impact of vegetative cover on runoff and soil erosion at hillslope scale in Lanjarón, The Environmentalist 24, 39-48.

Durán Z.V.H., Martínez R.A., Aguilar R.J. (2004b) Nutrient losses by runoff and sediment from the taluses of orchard terraces, Water Air Soil Poll. 153, 355-373.

Durán Z.V.H., Aguilar R.J., Martínez R.A., Franco D.T. (2005) Impact of erosion in the taluses of subtropical orchard terraces, Agr. Ecosyst. Environ. 107, 199-210.

Durán Z.V.H., Francia M.J.R., Rodríguez P.C.R., Martínez R.A., Cárceles R.B. (2006a) Soil erosion and runoff prevention by plant covers in a mountainous area (SE Spain): implications for sustainable agriculture, The Environmentalist 26, 309-319.

Durán Z.V.H., Rodríguez P.C.R., Franco T.D., Martín P.F.J. (2006b) El cultivo del chirimoyo (Annona cherimola Mill.), Granada, Spain.

Durán Z.V.H., Rodríguez P.C.R., Francia M.J.R., Cárceles R.B., Martínez R.A., Pérez G.P. (2007) Harvest intensity of aromatic shrubs vs. soil-erosion: an equilibrium for sustainable agriculture (SE Spain), Catena (in press) available on line at: www.sciencedirect.com.

EEA (2001) European Environmental Agency, available on line at http://www.eea.europa.eu/.

Elwell H.A. (1980) Design of safe rotational systems, Department of conservation and Extension, Harare, Zimbabwe, $50 \mathrm{pp}$.

Elwell H.A., Stocking M.A. (1974) Rainfall parameters and a cover model to predict runoff and soil loss from grazing trials in the Rhodesian sandveld, Proc. Grassland Soc. South Africa 9, 157-164.

Elwell H.A., Stocking M.A. (1976) Vegetal cover to estimate soil erosion hazard in Rhodesia, Geoderma 15, 61-70.

Faeth P., Crosson P. (1994) Building the case for sustainable agriculture, Environment 36, 16-20.

FAO (1998) Food Balance Sheet, available on line at: http://www.fao.org/es/ess/consweb.asp.

Faulkner H. (1990) Vegetation cover density variations and infiltration patterns on piped alkali sodic soils: Implications for the modelling of overland flow in semi-arid areas, in: Thornes J.B. (Ed.), Vegetation and Erosion, Processes and Environments, Wiley, Chichester, UK, pp. 317-346.

Flanagan D.C., Nearing M.A. (1995) USDA-Water Erosion Prediction Project (WEPP), hillslope profile and watershed model documentation, West Lafayette, in: US Department of AgricultureAgricultural Research Service, National Soil Erosion Research Laboratory Report 10.

Fox D.M., Bissonnais Y.L. (1998) Process-based analysis of aggregate stability effects on sealing, infiltration, and interrill erosion, Soil Sci. Soc. Am. J. 62, 717-724.

Fox D.M., Bryan R.B., Fox C.A. (2004) Changes in pore characteristics with depth for structural crusts, Geoderma 120, 109-120.

Francia J.R., Durán Z.V.H., Martínez R.A. (2006) Environmental impact from mountainous olive orchards under different soil-management systems (SE Spain), Sci. Total. Environ. 358, 46-60.

Francis C.F., Thornes J.B. (1990) Runoff hydrographs from three Mediterranean vegetation cover types, in: Thornes J.B. (Ed.), Vegetation and Erosion, Processes and Environments, Wiley, Chichester, UK, pp. 363-384.

Garcia R.J.M., Lasanta T., Marti C., Gonzáles C., White S., Ortigosa L., Ruiz F.P. (1995) Changes in runoff and erosion as a consequence of land-use changes in the central Spanish Pyrenees, Phys. Chem. Earth 20, 301-307.

Ghidey F., Alberts E.E. (1997) Plant root effects on soil erodibility, splash detachment, soil strength and aggregate stability, Trans. Am. Soc. Agr. Eng. 40, 129-135.

Glinski J., Lipiec J. (1990) Soil physical conditions and plant roots, CRC Press, Boca Raton, FL, USA.
Gobin A., Govers G., Jones R., Kirkby M., Kosmas C. (2003) Assessment and reporting on soil erosion European Environment Agency, Technical Report 94, Copenhagen, Denmark, 103 p.

González H.J.C., de Luis M., Raventós J., Cortina J., Sánchez J.R. (2004) Hydrological response of Mediterranean gorse shrubland under extreme rainfall simulation event, Z. Geomorphol. 48, 293-304.

Govers G., Everaert W., Poesen J., Rauws G., De Ploey J., Latridou J.P. (1990) A long flume study of the dynamic factors affecting the resistance of a loamy soil to concentrated flow erosion, Earth Surf. Proc. Land. 11, 515-524.

Gray D.H., Leiser A.T. (1982) Biotechnical Slope Protection and Erosion Control, Van Nostrand Reinhold Company, New York, USA.

Gray D.H., Sotir R.B. (1996) Biotechnical and Soil Bioengineering Slope Stabilization: A Practical Guide for Erosion Control, John Wiley and Sons, Toronto, Canada.

Greene R.S.B., Cartres C.J., Hodgkinson K.C. (1990) The effects of fire on the soils in a degraded semiarid woodland. I: Cryptogram cover and physical and micromorphological properties, Aust. J. Soil Res. 28, 755-777.

Greene R.S.B., Kinnell P.I.A., Wood J.T. (1994) Role of plant cover and stock trampling on runoff and soil erosion from semi-arid wooded rangelands, Aust. J. Soil Res. 32, 953-973.

Gregorich E.G., Greer K.J., Anderson D.W., Liang B.C. (1998) Carbon distribution and losses: erosion and depositional effects, Soil Till. Res. 47, 291-302.

Gutierrez J., Hernandez I.I. (1996) Runoff and interrill erosion as affected by grass cover in a semi-arid rangeland of northern Mexico, J. Arid Environ. 34, 287-295.

Grove A.T., Rackham O. (2001) The nature of Mediterranean Europe: an ecological history, Yale University Press, London, UK.

Gyssels G., Poesen J. (2003) The importance of plant root characteristics in controlling concentrated flow erosion rates, Earth Surf. Proc. Land. 28, 371-384.

Gyssels G., Poesen J., Bochet E., Li Y. (2005) Impact of plant roots on the resistance of soils to erosion by water: a review, Prog. Phys. Geog. 2, 189-217.

Gyssels G., Poesen J., Liu G., Van Dessel W., Knapen A., de Baets S. (2006) Effects of cereal roots on detachment rates of single and double drilled topsoils during concentrated flow, Eur. J. Soil Sci. 57, 381-391.

Harden J.W., Trumbore S.E., Stocks B.J., Hirsch A., Gower S.T., O’Neill K.P. (2000) The role of fire in the boreal carbon budget, Global Change Biol. 6, 174-184.

Heywood V.H. (1995) Global biodiversity assessment, Cambridge University Press, Cambridge.

Kaihura F.B.S., Kullaya I.K., Kilasara M., Aune J.B., Singh B.R., Lal R. (1999) Soil quality of accelerated erosion and management systems in three eco-regions of Tanzania, Soil Till. Res. 53, 59-70.

Kainz M. (1989) Runoff, erosion and sugar beet yields in conventional and mulched cultivation results of the 1988 experiment, Soil Technol. Series 1, 103-114.

Kendall H.W., Pimentel D. (1994) Constraints on the expansion of the global food supply, Ambio 23, 198-205.

Kitazawa Y., Kitazawa T. (1980) Influence of application of a fungicide, an insecticide, and compost upon soil biotic community, in: Sindal D.L. (Ed.), Soil Biology as Related to Land Use Practices, Office of Pesticide and Toxic Substances, Environmental Protection Agency, Washington DC, USA, pp. 94-99.

Kort J., Collins M., Ditsch D. (1998) A review of soil erosion potential associated with biomass crops, Biomass Bioenerg. 14, 351-359.

Kosmas C., Danalatos N., Moustakas N., Tsatiris B., Kallianou C., Yassoglou N. (1993) The impacts of parent material and landscape position on drought and biomass production of wheat under semiarid conditions, Soil Technol. 6, 337-349. 
Kosmas D., Danalatos N., Cammeraat L.H., Chabart M. (1997) The effect of land use on runoff and soil erosion rates under Mediterranean conditions, Catena 29, 45-59.

Kosmas C., Danalatos N.G., Gerontidis St. (2000) The effect of land parameters on vegetation performance and degree of erosion under Mediterranean conditions, Catena 40, 3-17.

Koulouri M., Giourga C. (2006) Land abandonment and slope gradient as key factors of soil erosion in Mediterranean terraced lands, Catena 69, 274-281.

Lasanta T., García R.J.M., Pérez R.C., Sancho M.C. (2000) Runoff and sediment yield in a semi-arid environment: the effect of land management after farmland abandonment, Catena 38, 265-278.

Lal R. (1990) Soil erosion and land degradation: the global risks, in: Lal R., Stewart B.A. (Eds.), Soil degradation, New York, USA, Springer-Verlag, pp. 129-172.

Lang R.D. (1979) The effect of ground cover on surface runoff from experimental plots, J. Soil Conserv. Service New South Wales 35, 108-114.

Lang R.D. (1990) The effect of ground cover on runoff and erosion plots at Scone, New South Wales, MSc Thesis, Macquarie University, Sydney, Australia.

Langdale G.W., West L.T., Bruce R.R., Miller W.P., Thomas A.W. (1992) Restoration of eroded soil with conservation tillage, Soil Technol. 5, 81-90.

Lavee H., Imeson A.C., Sarah P. (1998) The impact of climate change on geomorphology and desertification along a Mediterranean-arid transect, Land Degrad. Dev. 9, 407-422.

Le Houerou H.N. (1981) Impact of man and his animals on Mediterranean vegetation, in: di Castri F., Specht R.L. (Eds.), Ecosystems of the world: Mediterranean shrublands, Elsevier, Amsterdam, The Netherlands, pp. 479-521.

Lee E., Foster R.C. (1991) Soil fauna and soil structure, Aust. J. Soil Res. $29,745-776$.

Lee K.H., Isenhart T.M., Schultz C., Mickelson S.K. (2000) Multispecies riparian buffers trap sediment and nutrients during rainfall simulations, J. Environ. Qual. 29, 1200-1205.

Liu S., Bliss N., Sundquist E., Huntington T.G. (2003) Modeling carbon dynamics in vegetation and soil under the impact of soil erosion and deposition, Global Biogeochem. Cy. 17, 1074.

Li Y., Zhu X., Tian J. (1991) Effectiveness of plant roots to increase the anti-scourability of soil on the Loess Plateau, Chinese Sci. Bull. 36, 2077-2082.

Li Y., Xu X., Zhu X.M., Tian J.Y. (1992) Effectiveness of plant roots on increasing the soil permeability on the Loess Plateau, Chinese Sci. Bull. 37, 1735-1738.

Li Y., Xu X., Zhu X.M. (1993) Effective model on the roots of Chinese pine plantation to improve the physical properties of soil in the Loess Plateau, Scientia Silvae Sinicae 29, 193-198.

López B.F., Alias L.J., Martínez J., Romero M.A., Marín P. (1991) Escorrentía y pérdida de suelo en calcisol pétrico bajo ambiente mediterráneo semiárido, Cuatern. Geomorfol. 5, 7-89.

Mamo M., Bubenzer G.D. (2001a) Detachment rate, soil erodibility and soil strength as influenced by living plant roots: Part II. Field study, Am. Soc. Agr. Eng. 44, 1175-1181.

Mamo M., Bubenzer G.D. (2001b) Detachment rate, soil erodibility and soil strength as influenced by living plant roots: Part I. Laboratory study, Am. Soc. Agr. Eng. 44, 1167-1174.

Mapa R.B. (1995) Effect of reforestation using Tectona grandis on infiltration and soil water retention, Forest Ecol. Manag. 77, 119-125.

Marchand H. (1990) Les Forêts Méditerranéennes, Enjeux et perspectives, Les fascicules du Plan Bleu, 2, Économica, Paris, France.
Marqués M.J., Jiménez L., Pérez R.R., García O.S., Bienes R. (2005) Reducing water erosion in a gypsic soil by combined use of organic amendment and shrub revegetation, Land Degrad. Dev. 16, 339350 .

Marqués M.J., Bienes R., Jiménez L., Pérez R.R. (2007) Effect of vegetal cover on runoff and soil erosion under light intensity events. Rainfall simulation over USLE plots, Sci. Total Environ. 378, 161165.

Marston R.B. (1952) General cover requirements for summer storm runoff control on Aspen sites in Northern Utah, J. Forest. 50, 303307.

Martínez R.A., Durán Z.V.H., Francia F.R. (2006) Soil erosion and runoff response to plant cover strips on semiarid slopes (SE Spain), Land Degrad. Dev. 17, 1-11.

Martínez-Casasnovas J.A., Ramos M.C., Ribes D.M. (2005) On site effects of concentrated flow erosion in vineyard fields: some economic implications, Catena 60, 129-146.

Martínez-Mena M., Rogel A.J., Castillo V., Alvadalejo J. (2002) Organic carbon and nitrogen losses influenced by vegetation removal in a semiarid Mediterranean soil, Biogeochemistry 61, 309-321.

McDonald M.A., Healey J.R., Stevens P.A. (2002) The effects of secondary forest clearance and subsequent land-use on erosion losses and soil properties in the Blue Mountains of Jamaica, Agr. Ecosyst. Environ. 92, 1-19.

McIntyre D.S. (1958) Permeability measurements of soil crusts formed by raindrop impact, Soil Sci. 85, 185-189.

Meyer L.D., Dabney S.M., Harmon W.C. (1995) Sediment-trapping effectiveness of stiff-grass hedges, Trans. Am. Soc. Agr. Eng. 38, 809-815.

Mills A.J., Fey M.V. (2004) Effects of vegetation cover on the tendency of soil to crust in South Africa, Soil Use Manag. 20, 308-317.

Moore T.R., Thomas D.B., Barber R.G. (1979) The influence of grass cover on runoff and soil erosion from soils in the Machakos area, Kenya, Trop. Agr. 56, 339-344.

Morgan R.P.C. (1992) Soil erosion in the northern countries of the European Community, EIW Workshop: Elaboration of a framework of a code of good agricultural practices, Brussels, Belgium.

Morgan R.P.C. (1996) Soil erosion and conservation, second edition, Harlow, UK, Longman.

Morgan R.P.C., Rickson R.J. (1990) Issues on soil erosion in Europe: the need for a soil conservation policy, in: Boardman J., Foster I.D.L., Dearing J.A. (Eds.), Soil Erosion on Agricultural Land, John Wiley and Sons.

Morin J., Benyamini Y. (1977) Rainfall infiltration into bare soils, Water Resour. Res. 13, 813-817.

Narain P., Singh R.K., Sindhwal N.S., Joshie P. (1998) Water balance and water use efficiency of different land uses in western Himalayan valley region, Agr. Water Manage. 37, 225-240.

Naylor L.A., Viles H.A., Carter N.E.A. (2002) Biogeomorphology revisited: looking towards the future, Geomorphology 47, 3-14.

Nearing M.A., Jetten V., Baffaut C., Cerdan O., Couturier A., Hernández M., Le Bissonnais Y., Nichols M.H., Nunes J.P., Renschler C.S., Souchére V., van Oost K. (2005) Modeling response of soil erosion, runoff to changes in precipitation, cover, Catena 61, 131-154.

Nicolau J.M., Solé-Benet A., Puigdefábregas J., Gutiérrez L. (1996) Effects of soil and vegetation on runoff along a catena in semi-arid Spain, Geomorphology 14, 297-309.

Nunes J.P.C., Seixas J. (2003) Impacts of extreme rainfall events on hydrological soil erosion patterns; application to a Mediterranean watershed, World Res. Rev. 15, 336-351.

Nunes J.P., Vieira G.N., Seixas J., Gonçalves P., Carvalhais N. (2005) Evaluating the MEFIDIS model for runoff, soil erosion prediction during rainfall events, Catena 61, 210-228. 
Ojima D.S., Staffor-Smith M., Beardsley M. (1995) Factors affecting carbon storage in semiarid and arid ecosystems, in: Squires V.R. (Ed.), Combating global warning by combating land degradation, UNEP, Nairobi, Kenya, pp. 60-68.

Oldeman L.R., Hakkeling R.T.A., Sombroek W.G. (1991) Glasod world map of the status of human-induced soil degradation (second revised edition), ISRIC, UNEP, Wageningen, The Netherlands.

Osterkamp W.R., Friedman J.M. (2000) The disparity between extreme rainfall events, rare floods - with emphasis on the semi-arid American West, Hydrol. Process. 14, 2817-2829.

Pardini G., Gispert M., Dunjó G. (2003) Runoff erosion and nutrient depletion in five Mediterranean soils of NE Spain under different land use, Sci. Total. Environ. 309, 213-224.

Packer P.E. (1951) An approach to watershed protection criteria, J. Forest. 49, 639-644.

Pickett S.T.A., Cadenasso M.L., Bartha S. (2001) Implications from the Buell-Small Succession Study for vegetation restoration, Appl. Veg. Sci. 4, 41-52.

Pilgrim D.H., Chapman T.G., Doran D.G. (1988) Problems of rainfallrunoff modelling in arid and semiarid regions, Hydrolog. Sci. J. 33, 379-400.

Pimentel D., Kounang N. (1998) Ecology and soil erosion in ecosystems, Ecosystems 1, 416-426.

Pimentel D., Garnick E., Berkowitz A., Jacobson S., Napolitano S., Black P., Valdes C.S, Vinzant B., Hudes E., Littman S. (1980) Environmental quality and natural biota, Bioscience 30, 750-755.

Pimentel D., Stachow U., Takacs D.A., Brubaker H.W., Dumas A.R., Meaney J.J., O'Neil J., Onsi D.E., Corzilius D.B. (1992) Conserving biological diversity in agricultural/forestry systems, Bioscience 42, 354-362.

Pimentel D., Harvey C., Resosudarmo P., Sinclair K., Kurz D., McNair M., Crist S., Sphpritz L., Fitton L., Saffouri R., Blair R. (1995) Environmental and economic costs of soil erosion and conservation benefits, Science 267, 1117-1123.

Pojasok T., Kay B.D. (1990) Effect of root exudates from corn and bromegrass on soil structural stability, Can. J. Soil Sci. 70, 351362 .

Prosser I.P., Dietrich W.E., Stevenson J. (1995) Flow resistance and sediment transport by concentrated overland flow in a grassland valley, Geomorphology 13, 71-86.

Puigdefábregas J., Sole A., Gutíerrez L., del Barrio G., Boer M. (1999) Scales and processes of water and sediment redistribution in drylands: results from the Rambla Honda field site in Southeast Spain, Earth Sci. Rev. 48, 39-70.

Puigdefábregas J. (2005) The role of vegetation patterns in structuring runoff and sediment fluxes in drylands, Earth Surf. Process. Landf. 30, 133-147.

Quinton J.N., Catt J.A., Wood G.A., Steer J. (2006) Soil carbon losses by water erosion: experimentation and modeling at field and national scales in the UK, Agr. Ecosyst. Environ. 112, 87-102.

Reid W.S. (1985) Regional effects of soil erosion on crop productivity: northeast, in: Follett R.F., Stewart B.A. (Eds.), Soil erosion and crop productivity, Madison, WI, USA, American Society of Agronomy, pp. 235-250.

Reid B.J., Goss M.J. (1987) Effect of living roots of different plant species on the aggregate stability of two arable soils, J. Soil Sci. 32, 521541.

Renard K.G., Foster G.R., Weesies G.A., McCool D.K., Yoder D.C. (1997) Predicting soil erosion by water: a guide to conservation planning with the revised universal soil loss equation (RUSLE), Washington, DC: US Department of Agriculture-Agricultural Research Service, Agriculture Handbook 703.
Renschler C.S., Harbor J. (2002) Soil erosion assessment tools from point to regional scales-the role of geomorphologists in land management research, implementation, Geomorphology 47, 189-209.

Renschler C.S., Mannaerts C., Diekkrueger B. (1999) Evaluating spatial, temporal variability in soil erosion risk; rainfall erosivity, soil loss ratios in Andalusia, Spain, Catena 34, 209-225.

Reubens B., Poesen J., Danjon F., Geudens G., Muys B. (2007) The role of fine and coarse roots in shallow slope stability and soil erosion control with a focus on root system architecture: a review, Trees 21, 385-402.

Rey F. (2003) Influence of vegetation distribution on sediment yield in forested marly gullies, Catena 50, 549-562.

Rickson R.J., Morgan R.P.C. (1988) Approaches to modelling the effects of vegetation on soil erosion by water, in: Morgan R.P.C., Rickson R.J. (Eds.), Agriculture: erosion assessment and modelling, Office for Official Publications of the European Communities, Luxembourg.

Rodríguez P.C.R., Durán Z.V.H., Martín P.F.J., Franco T.D. (2007a) Erosion rates and carbon losses under different plant covers in the taluses of subtropical orchard terraces, in: Abad Chabbi (Ed.), International Symposium on Organic Matter Dynamics in AgroEcosystems, Poitiers, France, pp. 326-327.

Rodríguez P.C.R., Durán Z.V.H., Martín P.F.J., Franco T.D. (2007b) Conservación del suelo y de su biodiversidad bajo diferentes cubiertas en terrazas de cultivos subtropicales, in: Rodríguez R.A., Arbelo D.C. (Eds.), Control de la degradación de suelos y la desertificación, III Simposio Nacional CDSD, Fuerteventura, Islas Canarias, Spain, pp. 413-414.

Roels J.M. (1985) Estimation of soil loss at a regional scale based on plot measurement. Some critical considerations, Earth Surf. Proc. Land. $10,587-595$.

Rogers R.D., Schumm S.A. (1991) The effect of sparse vegetative cover on erosion and sediment yield, J. Hydrol. 123, 19-24.

Romero D.M.A., López-Bermúdez F., Thornes J.B., Francis C.F., Fisher G.C. (1988) Variability of overland flow erosion rates in semiarid Mediterranean environment under matorral cover. Murcia Spain, in: Harvey A.M., Salas M. (Eds.), Geomorphic Systems, Catena Supplement, Vol. 13, pp. 1-11.

Romero D.M.A., Cammeraat L.H., Vacca A., Kosmas C. (1999) Soil erosion at three experimental sites in the Mediterranean, Earth Surf. Proc. Land. 24, 1243-1256.

Romero R., Guijarro J.A., Ramis C., Alonso S. (1998) A 30-year (19641993) daily rainfall data base for the Spanish Mediterranean regions: first exploratory study, Int. J. Climatol. 18, 541-560.

Roose E. (1988) Soil and water conservation lessons from steepslope farming in French speaking countries of Africa, in: Conservation farming on steep lands. Ankeny (IA): Soil and Water Conservation Society, pp. 130-131.

Rostagno C.M., del Valle Puerto M.H.F. (1988) Mounds associated with shrubs in aridic soils of northeastern Patagonia: characteristics and probable genesis, Catena 15, 347-359.

Ryan C. (1995) Assessment of the factors contributing to the aggregate stability and the erodibility of tropical highland soils. Soil Fertility Conservation Project and Carleton University, Ottawa.

Sakkar A.N., Jenkins D.A., Wyn Jones R.G. (1979) Modifications to mechanical and mineralogical composition of soil within the rhizosphere, in: Harley J.L., Russell R.S. (Eds.), The soil-plant interface, Academic Press, London, UK.

Sala M., Calvo A. (1990) Response of four different Mediterranean vegetation types to runoff and erosion, in: Thornes J.B. (Ed.), Vegetation and Erosion, Wiley and Sons, Ltd., New York, USA, pp. 347-362. 
Sanchez G., Puigdefabregas J. (1994) Interactions of plant-growth and sediment movement on slopes in a semiarid environment, Geomorphology 9, 243-260.

Scharpenseel H.W., Pfeiffer E.M. (1998) Impacts of possible climate change upon soils; some regional consequences, in: Blume H.P. (Ed.), Towards a sustainable land use, Advances in Geoecology 31, Vol. 1, Catena-Verlag, Germany, pp. 193-208.

Schenk H.J., Jackson R.B. (2002) The global biogeography of roots, Ecol. Monogr. 72, 311-328.

Schertz D.L., Moldenhauer W.C., Livingston S.J., Weesies G.A., Hintz E.A. (1989) Effect of past soil erosion on crop productivity in Indiana, J. Soil Water Conserv. 44, 604-608.

Schlesinger W.H., Reynolds J.F., Cunningham G.L., Huenneke L.F., Jarrell W.M., Virginia R.A., Whitford W.G. (1990) Biological feedbacks in global desertification, Science 247, 1043-1048.

Shainberg I. (1992) Chemical and mineralogical components of crusting, in: Sumner M.E., Stewart B.A. (Eds.), Soil Crusting: Chemical and Physical Processes, Lewis Publishers, Boca Raton, FL, USA, pp. 33-53.

Sheridan G.J., So H.B., Loch R.J., Walker C.M. (2000) Estimation of erosion model erodibility parameters from media properties, Aus. J. Soil Res. 38, 256-284.

Skiba U., Cresser M.S. (1991) Seasonal changes in soil atmospheric $\mathrm{CO}_{2}$ concentrations in two upland catchments and associated changes in river water chemistry, Chem. Ecol. 7, 217-225.

Smith P., Goulding K.W., Smith K.A., Powlson D.S., Smith J.U., Falloon P.D. (2001a) Enhancing the carbon sink in European agricultural soils: including trace gas fluxes in estimates of carbon mitigation potential, Nutr. Cycl. Agroecosyst. 60, 237-252.

Smith S.V., Renwick W.H., Buddenmeier R.W., Crossland C.J. (2001b) Budgets of soil erosion and deposition for sediments and sedimentary organic carbon across the conterminous United States, Glob. Biogeochem. Cycles 15, 697-707.

Snelder D.J., Bryan R.B. (1995) The use of rainfall simulation test to assess the influence of vegetation density on soil loss on degraded rangelands in the Baringo District, Kenya, Catena 25, 105-116.

Squires V. (1998) Dryland soils: their potential as a sink for carbon and as an agent in mitigating climate change, in: Blume H.P. (Ed.), Towards a sustainable land use, Advances in Geoecology 31, Vol. 1, Catena-Verlag, Germany, pp. 209-215.

Sidorchuk A., Grigorev V. (1998) Soil erosion in the Yamal Peninsula (Russian Arctic) due to gas field exploitation, Adv. GeoEcology 31, 805-811.

Simon A., Collison A. (2001) Scientific basis for streambank stabilization using riparian vegetation, Proceedings of the 7th Federal Interagency Sedimentation Conference, March 25-29, 2001, Reno, Nevada, USA.

Singer M.J., Shainberg I. (2004) Mineral soil surface crusts and wind and water erosion, Earth Surf. Proc. Land. 29, 1065-1075.

Sorriso V.M., Bryan R.B., Yair A., Iovino F., Antronico L. (1995) Impact of afforestation on hydrological response and sediment production in a small Calabrian catchment, Catena 25, 89-104.

Soto B., Díaz F.F. (1997) Runoff and soil erosion from areas of burnt scrub: comparison of experimental results with those predicted by the WEPP model, Catena 31, 257-270.

Stallard R.F. (1998) Terrestrial sedimentation and the carbon cycle: coupling weathering and erosion to carbon burial. Global. Biogeochem. Сy. 12, 231-257.

Soussana J.F., Loiseau P., Vuichard N., Ceschia E., Balesdent J., Chevallier T. (2004) Carbon cycling and sequestration opportunities in temperate grasslands, Soil Use Manag. 20, 19-23.
Stroosnijder L. (2005) Measurement of erosion: is it possible? Catena 64, $162-173$

Styczen M.E., Morgan R.P.C. (1995) Engineering properties of vegetation, in: Morgan R.P.C., Rickson R.J. (Eds.), Slope Stabilization and Erosion Control: A Bioengineering Approach, E. \& F.N. Spon, London, UK, pp. 5-58.

Tengbeh G.T. (1993) The effect of grass roots on shear strength variations with moisture content, Soil Tech. 6, 287-295.

Tisdall J.M., Oades J.M. (1982) Organic matter and water-stable aggregates in soils, J. Soil Sci. 33, 141-163.

Thirgood J.V. (1981) Man and the Mediterranean forest, Academic press, New York, USA.

Trimble S.W. (1990) Geomorphic effects of vegetation cover and management: some time and space considerations in prediction of erosion and sediment yield, in: Thornes J.B. (Ed.), Vegetation and Erosion Processes and Environments, John Wiley and Sons.

Turkelboom F., Poesen J., Ohler I., van Keer K., Ongprasert S., Vlassak K. (1997) Assessment of tillage erosion rates on steep slopes in northern Thailand, Catena 29, 29-44.

USDA (2001) Agricultural Statistics, Washington, DC, USDA.

Vacca A., Loddo S., Ollesch G., Puddu R., Serra G., Tomasi D., Aru A. (2000) Measurement of runoff and soil erosion in three areas under different land use in Sardinia (Italy), Catena 40, 69-92.

Van Oost K., Govers G., Quine T.A., Heckrath G., Olesen J.E., De Gryze S. (2005) Landscape-scale modeling of carbon cycling under the impact of soil redistribution: the role of tillage erosion, Global. Biogeochem. Cy. 19, GB4014 doi: 10.1029/2005GB002471.

Van Dijk P.M., Kwaad F.J.P.M., Klapwijk M. (1996) Retention of water and sediment by grass strips, Hydrol. Process. 10, 1069-1080.

Van Lynden G.W.J. (1995) European soil resources, Nature and Environment, No. 71. Council of Europe, Strasbourg.

Valentin C. (1991) Surface crusting in two alluvial soils of northern Niger, Geoderma 48, 210-222.

Valentin C., Bresson L.M. (1992) Morphology, genesis and classification of surface crusts in loamy and sandy soils, Geoderma 55, 225-245.

Wainwright J. (1996) Infiltration, runoff and erosion characteristics of agricultural land in extreme storm event, SE France, Catena 26, $27-$ 47.

Wainwright J., Parsons A.J., Schlesinger W.H. (2002) Hydrologyvegetation interactions in areas of discontinuous flow on a semi-arid bajada, Southern New Mexico, J. Arid Environ. 51, 319-338.

Wen D., Pimentel D. (1998) Agriculture in China: water and energy resources, in: Tso T.C., Tuan F., Faust M. (Eds.), Agriculture in China 1949-2030, Beltsville, IDEALS Inc., pp. 479-497.

West L.T., Chiang S.C., Norton L.D. (1992) The morphology of surface crusts, in: Sumner M.E., Stewart B.A. (Eds.), Soil Crusting: Chemical and Physical Processes. Lewis Publishers, Boca Raton, FL, USA. pp. 73-92.

Whittaker R.H., Likens G.E. (1973) Primary production in the biosphere and man, Hum. Ecol. 1, 357-369.

Wilcox B., Wood K. (1988) Hydrologic impacts of sheep grazing on steep slopes in semiarid rangelands, J. Range Manage. 41, 303-306.

Wilcox B., Wood K. (1989) Factors influencing interrill erosion from semiarid slopes in New Mexico, J. Range Manage. 42, 66-70.

Wischmeier W.H. (1975) Estimating the soil loss equation's cover and management factor for undisturbed areas, Proceedings of the Sediment-Yield Workshop, 1972, Oxford, MI, USA Department of Agriculture Research Service ARS-S-40, pp. 118-124. 
Wood M. (1989) Soil biology, Blackie, Chapman and Hall, New York.

WRI (1997) World Resources Institute, New York, Oxford University Press.

Wright D.H. (1990) Human impacts on energy flow through natural ecosystems, and replications for species endangerment, Ambio 19, 189-194.

Yaalon D.H. (1990) Soils of a warmer earth, projecting the effects of increased $\mathrm{CO}_{2}$ and gaseous emissionon soils in Mediterranean and subtropical regions, in: Scharpenseel H.W. (Ed.), Soil on a Warmer Earth, Development in Soil Science 20, Elsevier, Amsterdam, The Netherlands, pp. 175-176.

Young A. (1990) Agroforestry, environment and sustainability, Outlook Agr. 19, 155-160.
Zanchi C. (1988) Soil loss, seasonal variation of erodibility in two soils with different texture in the Muguello valley in central Italy, Catena Supplement 12, 167-173.

Zhang B., Yang Y., Zepp H. (2004) Effect of vegetation restoration on soil and water erosion and nutrient losses of a severely eroded clayey Plinthudult in southeastern China, Catena 57, 77-90.

Zhou G.Y., Morris J.D., Yan J.H., Yu Z.Y., Peng S.L. (2002) Hydrological impacts of reafforestation with eucalypts and indigenous species: a case study in southern China, Forest Ecol. Manag. 167, 209-222.

Zhou Z., Shangguan Z. (2005) Soil anti-scourability enhanced by plant roots, J. Integrated Plant Biol. 47, 676-682.

Ziegler A.D., Giambelluca T.W. (1998) Influence of revegetation efforts on hydrologic response and erosion, Kaho'Olawe Island, Hawaii, Land Degrad. Dev. 9, 189-206. 